\title{
The human cutaneous chemokine system
}

\author{
Michelle L. McCully and Bernhard Moser* \\ Department of Infection, Immunity and Biochemistry, School of Medicine, Cardiff University, Cardiff, UK
}

\section{Edited by:}

Mario Mellado, Consejo Superior de Investigaciones Científicas, Spain

\section{Reviewed by:}

Cory Michel Hogaboam, University of Michigan Medical School, USA

José Luis Rodríguez-Fernández,

Consejo Superior de Investigaciones

Cientificas, Spain

*Correspondence:

Bernhard Moser, Department of Infection, Immunity and Biochemistry, School of Medicine, Cardiff University, Heath Park, Cardiff CF14 4XN, UK.

e-mail:moserb@cf.ac.uk
Irrespective of the immune status, the vast majority of all lymphocytes reside in peripheral tissues whereas those present in blood only amount to a small fraction of the total. It has been estimated that T cells in healthy human skin outnumber those present in blood by at least a factor of two. How lymphocytes within these two compartments relate to each other is not well understood. However, mounting evidence suggest that the study of $T$ cell subsets present in peripheral blood does not reflect the function of their counterparts at peripheral sites. This is especially true under steady-state conditions whereby long-lived memory $T$ cells in healthy tissues, notably those in epithelial tissues at body surfaces, are thought to fulfill a critical immune surveillance function by contributing to the first line of defense against a series of local threats, including microbes, tumors, and toxins, and by participating in wound healing. The relative scarcity of information regarding peripheral $T$ cells and the factors regulating their localization is primarily due to inherent difficulties in obtaining healthy tissue for the extraction and study of immune cells on a routine basis. This is most certainly true for humans. Here, we review our current understanding of T cell homing to human skin and compare it when possible with gut-selective homing. We also discuss candidate chemokines that may account for the tissue selectivity in this process and present a model whereby $C C R 8$, and its ligand $C C L 1$, selectively regulate the homeostatic migration of memory lymphocytes to skin tissue.

Keywords: Human, skin, immune surveillance, memory T cells, chemokines, homing

\section{INTRODUCTION}

Chemokines control leukocyte migration and fulfill essential functions in homeostatic and inflammatory immune processes. Homeostatic chemokines control leukocyte traffic taking place in the absence of inflammatory stimuli whereas inflammatory chemokines are inducible and, therefore, control effector cell recruitment to the site of infection and disease where inflammatory chemokines are being produced. Chemokines and their receptors do not work alone but instead require the concerted "trans" action of cellular adhesion molecules that, figuratively speaking, provide the necessary "traction" for cell migration. The combination of chemokine receptors and adhesion molecules define distinct address codes, based upon which leukocytes can either remain in circulation or become engaged in secondary lymphoid organs or gain access to peripheral tissues. The checkpoints for leukocyte relocation are (i) the microvascular beds where selected leukocytes exit the bloodstream via trans-endothelial migration, (ii) the specific site(s) of chemokine production within the tissue where migrating leukocytes interact with their target cells, and (iii) the lymphatic vasculature controlling leukocyte exit from healthy or inflamed tissues. Detailed knowledge about a cell's address code provides much information about its functional "quality." Consequently, the expression studies of distinct chemokine and adhesion receptor combinations have been useful in functionally defining

Abbreviations: $1,25(\mathrm{OH})_{2} \mathrm{D}_{3}, \quad$ 1,25-dihydroxycholecalciferol; APC, antigenpresenting cells; DC, dendritic cells; DETC, dendritic epidermal T cell; iTreg, induced Treg; LC, Langerhans cells; RA, retinoic acid; Treg, regulatory T cell. the various leukocyte subsets, as best exemplified by distinct classes of $\mathrm{T}$ helper cells. In humans, most chemokine studies have been performed with fresh or cultured leukocytes derived from peripheral blood. Here, we summarize our current knowledge about the chemokine system in human skin and compare it (where allowed) with the situation in mice. Human skin is constantly exposed to a large variety of environmental hazards that include UV irradiation, toxins, as well as commensal, and pathogenic microbes. The species-specific environment and extended life span may explain in part why human skin differs profoundly from standard laboratory animals (rodents) in terms of tissue architecture and immune cell composition. We will discuss the role of chemokines in regulating tissue-selective homing of memory $\mathrm{T}$ cells with particular focus on human skin, and propose a model whereby the skin-selective homing of immune surveillance $\mathrm{T}$ cells in humans is regulated by CCL1 and its receptor CCR8. We also raise several unresolved issues that are relevant for understanding tissue immune surveillance and vaccination responses.

\section{THE SKIN VERSUS GUT HOMING DICHOTOMY}

Several excellent review articles discuss the substantial progress achieved in mouse experiments targeting the role of chemokines and adhesion molecules in the tissue-specific homing of leukocytes (Agace, 2008; Mora et al., 2008; Sigmundsdottir and Butcher, 2008; Woodland and Kohlmeier, 2009; del Rio et al., 2010). This research was based on earlier observations describing the correlation between the sites of immune activation (vaccination) with the instruction of tissue-homing properties in effector/memory 
$\mathrm{T}$ cells during immune response initiation in the draining lymph nodes. In essence, the current paradigm is simple and calls for the targeted release of tissue-derived factors during $\mathrm{T}$ cell priming that instruct the tissue-specific leukocyte homing. For the gut, the expression CCR9 together with $\alpha 4 \beta 7$ (or $\alpha_{E} \beta 7$ ) has been correlated with the metabolism of vitamin A (retinol; Figure 1). The bulk of dietary vitamin A is stored in the liver and is released in the form of a complex with a protein chaperon (retinol-binding protein) to ensure a steady-state level in blood circulation and peripheral tissues (Niederreither and Dolle, 2008). The necessity of vitamin A in organ development and eyesight is well established, but it is becoming increasingly clear that vitamin A metabolites also affect DC functions and, as briefly discussed here, T cell mobilization. In the gut, $\mathrm{CD}_{103}{ }^{+} \mathrm{DCs}$ process vitamin $\mathrm{A}$ to retinoic acid (RA), which acts on the nuclear receptors, composed of the retinoic acid receptor (RAR), and the retinoic X receptor (RXR). Of note, RXR is also shared with the vitamin D receptor (VDR; see below). Elegant studies have now shown (i) that RA instills gut-homing receptors (CCR9, $\alpha 4 \beta 7$ ) on murine T cells (Iwata et al., 2004), and (ii) that gut-associated DCs express elevated levels of vitamin A-processing enzymes leading to the localized release of RA that triggers CCR9 and $\alpha 4 \beta 7$ expression in $\mathrm{T}$ cells (Coombes et al., 2007; Jaensson et al., 2008; Guilliams et al., 2010). The proximity of DCs and
T cells may ensure the undiluted transfer of DC-derived factors, including RA, to responding $\mathrm{T}$ cells in the lymph nodes, although the underlying mechanisms have not been studied. Mouse studies have revealed that RA production is a particular feature of $\mathrm{CD}_{103}{ }^{+} \mathrm{DCs}$, which predominate in gut tissue whereas CD103DCs are less efficient in doing so (Johansson-Lindbom et al., 2005; Jaensson-Gyllenback et al., 2011). Intestinal CD103+ DCs and RA are also involved in the induction of CCR9 and $\alpha 4 \beta 7$ in humans T cells (Jaensson et al., 2008; Eksteen et al., 2009). Still, further studies are needed to evaluate the relative contribution of gut DCs versus tissue cells, such as intestinal epithelial cells that are also capable of producing RA (Edele et al., 2008), or lymph node stromal cells, which may be responsible for licensing DCs to process RA (Hammerschmidt et al., 2008; Molenaar et al., 2009). Nevertheless, the selective metabolism of vitamin A by gut-associated $\mathrm{CD} 103^{+} \mathrm{DCs}$ and its effect on expression of gut-homing receptors on T cells fits nicely with the above-mentioned tissue-homing paradigm.

With respect to skin, recent evidence suggest the involvement of another vitamin, vitamin $\mathrm{D}_{3}$, and especially its active metabolite 1,25 -dihydroxycholecalciferol $\left(1,25(\mathrm{OH})_{2} \mathrm{D}_{3}\right)$, as the environmental cue for induction of the skin-selective homing receptor CCR10 (Mora et al., 2008; Sigmundsdottir and Butcher, 2008;

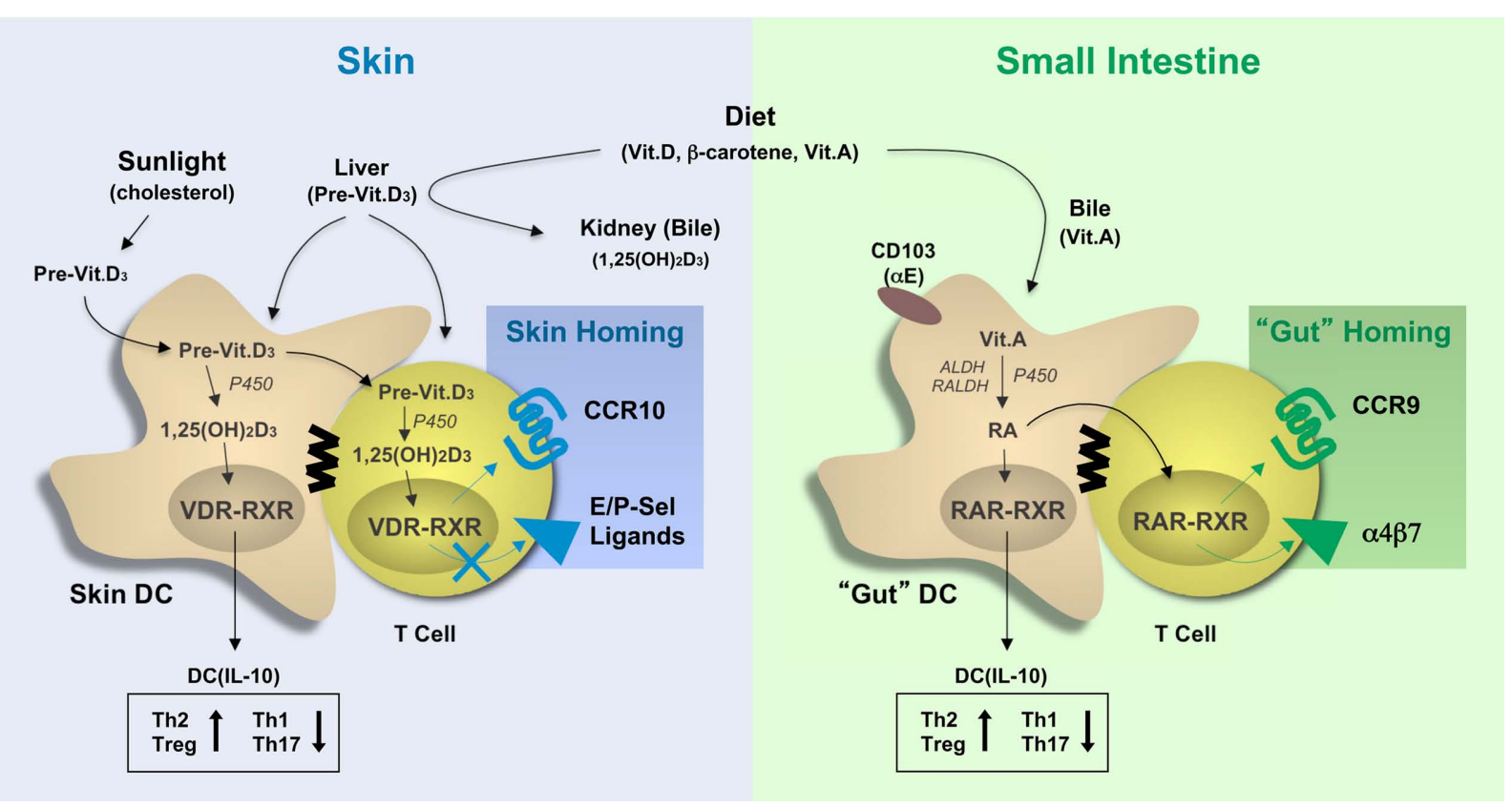

FIGURE 1 | The involvement of vitamins in the programming of tissue tropic $\mathbf{T}$ cells. Vitamins and vitamin precursors are provided by the diet and, in the case of vitamin $D_{3}$, sun exposure and stored as inactive precursors in the liver or bile. Vitamins $A$ and $D$ precursors can be further processed to their active metabolites, retinoic acid (RA), and 1,25-dihydroxycholecalciferol $\left(1,25(\mathrm{OH})_{2} \mathrm{D}_{3}\right)$, respectively, by tissue-resident dendritic cells and, in some cases T cells, by processes involving intracellular hydroxylases (P450) and dehydrogenases (ALDH, RALDH). These active compounds bind to vitamin D (VDR-RXR) and retinoic acid (RAR-RXR) receptors in the nucleus leading to induction of gene expression, which affects both DC maturation and T helper cell differentiation. RA and
$1,25(\mathrm{OH})_{2} \mathrm{D}_{3}$ signaling in $\mathrm{DC}$ have both been shown to promote IL-10 production and skew T cell differentiation toward Th2 and Treg development, while signaling in $T$ cells affects the expression of adhesion molecules and chemokine receptors. Specifically, activation of RAR-RXR-dependent gene expression leads to the expression of the gut-homing receptors CCR9 and $\alpha 4 \beta 7$, while activation of VDR-RXR induces CCR10 expression but not the expression of CLA, the skin-specific ligand for E/P-selectin. 1,25(OH) ${ }_{2} D_{3}$, 1,25-dihydroxycholecalciferol $\left(1,25(\mathrm{OH})_{2} \mathrm{D}_{3}\right)$; RA, retinoic acid, $\mathrm{P} 450$, cytochrome P450; ALDH, alcohol dehydrogenases; RALDH, retinal dehydrogenases, VDR, vitamin $D$ receptor; RAR, retinoic acid receptor; RXR, retinoid $\mathrm{X}$ receptor. 
Figure 1). However, the expression of other skin homing receptors, including human cutaneous T lymphocyte antigen (CLA), mouse P/E-selectin ligands, and CCR4, are not affected or in some cases even inhibited by vitamin $\mathrm{D}_{3}$ (Sokolov et al., 2009). In addition to dietary uptake, vitamin $\mathrm{D}_{3}$ is produced in skin in response to solar UV-B irradiation from 7-dehydrocholesterol (Reichrath, 2007). In fact, there is no need for dietary vitamin $D_{3}$ supplementation, except in immunosuppressed patients (e.g., transplant recipients) who need to avoid sun exposure and in the elderly. Vitamin $\mathrm{D}_{3}$ is metabolized to its active form, $1,25(\mathrm{OH})_{2} \mathrm{D}_{3}$, by hydrolases in the liver and kidney as well as in skin cells, including keratinocytes and dendritic cells. Similar to RA, $1,25(\mathrm{OH})_{2} \mathrm{D}_{3}$ binds to heterodimeric nuclear receptors composed of the VDR and RXR, which then trigger gene expression by interacting with vitamin D response elements (VDREs). More importantly, VDREs are present in the promoter region of human but not mouse CCR10, which may explain the inability of $1,25(\mathrm{OH})_{2} \mathrm{D}_{3}$ to induce CCR10 expression in mouse T cells (Sigmundsdottir et al., 2007). Nocturnal or furry animals, which lack cutaneous vitamin $\mathrm{D}_{3}$ production, likely evolved a different mechanism for imprinting skin homing properties in effector/memory $\mathrm{T}$ cells. This is supported by the finding that skin-derived DCs from both mice (lacking vitamin $\mathrm{D}_{3}$ metabolites) and humans are capable of inducing a skin homing phenotype in responding $\mathrm{T}$ cells, indicating that certain, as yet undefined skin "factors" are likely to instruct local DCs in both species (Mora et al., 2005). Furthermore, the tissue-homing program of peripheral DCs can be overridden when exposed to alternative tissue environments, demonstrating the plasticity of DCs to instruct tissue-homing properties in $\mathrm{T}$ cells and, importantly, the presence of multiple and functionally overlapping tissue factors (Dudda et al., 2005; Rimoldi et al., 2005; Edele et al., 2008; Hammerschmidt et al., 2008; Iliev et al., 2009).

The vitamin A-vitamin $\mathrm{D}_{3}$ dichotomy in controlling homing properties in $\mathrm{T}$ cells during peripheral immune responses provides a plausible explanation for the observed traffic of engaged T cells to distinct peripheral sites. But many more questions remain.

\section{VITAMINS}

The finding that vitamin A induces CCR9 and integrin receptor expression in $\mathrm{T}$ cells represents an important discovery (Iwata et al., 2004). Yet, it is undisputed that the principal role of vitamin $A$ (and vitamin $D_{3}$ ) is not the instruction of $T$ cell migration programs but rather the control of crucial and diverse metabolic processes. Vitamin A metabolism also occurs in sites other than the gut, including skin, where the treatment of disorders of keratinization, such as Psoriasis, using topical, and/or oral retinoids is well established (Roos et al., 1998). In addition, vitamin A controls integrin $\alpha 4$ expression, which when combined with the $\beta 1$ chain is frequently involved in T cell recruitment to inflammatory sites (Kang et al., 2011), and vitamin $\mathrm{D}_{3}$ was shown to inhibit the expression of the skin homing adhesion molecule CLA (Yamanaka et al., 2008). Furthermore, vitamins $A$ and $D_{3}$ have a general effect of DC function leading to Th2 and iTreg cell differentiation in responding $\alpha \beta$ T cells (Mora et al., 2008; Figure 1). Of interest, VDR-deficient mice do not show gross abnormalities in $\mathrm{T}$ cell compartmentalization. Collectively, it is reasonable to assume that the control of tissue-homing properties in T cells is more complex than previously appreciated.

\section{EFFECTOR VERSUS MEMORY T CELLS}

Effector T cells, i.e., activated, short-lived T cells generated during the onset of immune responses, not only travel to the tissue in which the DCs have captured and processed the cognate antigens, but disperse widely to other non-involved organs as well (Reinhardt et al., 2001; Liu et al., 2006; Brinkman et al., 2008). By doing so, effector T cells may forestall dissemination of infectious agents to other sites, but from the standpoint of homing, it means that a particular tissue tropism induced during contact with tissuederived DCs does not override alternative trafficking routes. This indicates that in early immune responses redundancy, as opposed to selectivity, is an essential element of protective immunity. As such, we hypothesize that memory $\mathrm{T}$ cells (i.e., resting, long-lived $\mathrm{T}$ cells that survive the $\mathrm{T}$ cell contraction phase) are the ones that preferentially respond the tissue-selective localization cues.

\section{HOMEOSTATIC VERSUS INFLAMMATORY T CELL TRAFFIC}

During inflammation, the main goal of the infected tissue is to recruit as many effector immune cells as possible. To do so, the local release of inflammatory mediators in conjunction with pathogen-derived products trigger an inflammatory cascade that results in the release of inflammatory chemokines and the expression of inducible adhesion molecules on microvascular endothelial cells. Inflammatory chemokines generally act on a large array of target cells and show a significant amount of redundancy in the recruitment of effector cells. As such, it is unclear to what extent tissue-selective homing mechanisms support the inflammatory chemokine-driven recruitment of effector cells. We postulate that tissue-selective immune cell homing operates under steadystate conditions and, thus, correlates with the tissue distribution and/or retention of resting memory cells. In the following section we discuss human skin as a site with specific needs for immune protection and summarize the literature dealing with cutaneous chemokines.

\section{CHEMOKINES PRESENT IN HUMAN SKIN}

In the gut, it is clear that the constitutive and selective expression of CCL25 by intestinal epithelial cells recruits CCR9-expressing lymphocytes to the small intestine, but the question still remains as to whether a similar mechanism regulates the specific migration of long-lived memory lymphocytes to skin tissue. Previous data implicate CCR4, CCR6, and CCR10 in the recruitment of effectors to mucosal sites in inflammation, but as we discuss below, these receptors are unlikely to regulate homeostatic migration. In order to identify potential candidates, one first needs to identify those chemokines that are expressed in skin and, much like CCL25 in the gut, are largely absent at other locations.

Numerous chemokines have been detected by various methods in human skin tissue (listed in Table 1) but few of these show skin-selective expression. Most skin chemokines are classified as inflammatory chemokines, meaning that they are upregulated under inflammatory conditions in order to target effector cells. Among those associated with inflammatory diseases are the CCR4 ligands CCL17 and CCL22. Both are produced by 
Table 1 | Chemokine expression in human skin.

\begin{tabular}{llll}
\hline Chemokine & Receptor & Type & Method $^{\mathbf{a}}$ \\
\hline CCL1 & CCR8 & $\begin{array}{l}\text { Steady state } \\
\text { Tissue culture }\end{array}$ & IHC/IF \\
& & PCR/RNase \\
& & PA/HC/ELISA \\
& & $\begin{array}{l}\text { Inflamed } \\
\text { CCL17/CCL22 }\end{array}$ & PCR \\
& & $\begin{array}{l}\text { Steady state } \\
\text { Tissue culture }\end{array}$ & IF \\
& & PCR/ELISA
\end{tabular}

\section{Remarks $^{\mathbf{b}}$}

Vascular EC of dermal plexus; LCs and melanocytes (Schaerli et al., 2004)

Dermal vascular EC and resting Langerhans-type DC; activated mast cells, skin T cells and dermal fibroblasts (Schaerli et al., 2004; Gombert et al., 2005; Ebert et al., 2006; Hintzen, 2008)

Allergic contact dermatitis (Sebastiani et al., 2001; Gombert et al., 2005; Gros et al., 2009) Low levels of CCL17 detected in dermal vessels of non-inflamed skin (Chong et al., 2004) Keratinocytes; dermal fibroblasts stimulated by inflammatory cytokines Nestergaard et al., 2000; Albanesi et al., 2001; Horikawa et al., 2002; Yu et al., 2002; Fukuda et al., 2003; Sumiyoshi et al., 2003)

Inflamed

$\mathrm{PCR} / \mathrm{ISH} /$

AD Nestergaard et al., 2000; Goebeler et al., 2001; D'Ambrosio et al., 2002; Horikawa microarray/lHC et al., 2002; Martin et al., 2002; Sebastiani et al., 2002; Uchida et al., 2002; Zheng et al., 2003; Echigo et al., 2004; Guttman-Yassky et al., 2007; Gros et al., 2009; Kamsteeg et al., 2010)

IHC Psoriasis (Rottman et al., 2001)

PCR/IHC Cutaneous T and B lymphoma (Ferenczi et al., 2002; Yoshie et al., 2002; Kakinuma et al., 2003b; Ishida et al., 2005; Harasawa et al., 2006)

IHC/ELISA Cutaneous lupus erythematosus Menzel et al., 2005)

PCR/IHC Drug-induced maculopapular exanthema (Tapia et al., 2007)

CCL20 CCR6 Steady state PCR/IHC

Constitutive low levels in basal epidermis; keratinocytes and dermal vascular EC (Charbonnier et al., 1999; Homey et al., 2000; Schmuth et al., 2002)

Tissue culture PCR/ELISA

Keratinocytes, melanocytes, dermal vascular and lymph. ECs and fibroblasts upon stimulation with inflammatory mediators (cytokines, TLRs, SAgetc), anti-microbial peptides, or allergens (Dieu-Nosjean et al., 2000; Homey et al., 2000, 2007; Kriehuber et al., 2001; Nakayama et al., 2001; Tohyama et al., 2001; Schmuth et al., 2002; Giustizieri et al., 2004; Meller et al., 2005; Spiekstra et al., 2005; Niyonsaba et al., 2007; Harper et al., 2009; Olaru and Jensen, 2010)

Inflamed

Function Memory T cell arrest on activated dermal EC (Fitzhugh et al., 2000; Ghannam et al., 2011) PCR/ISH/RNA Psoriasis (Charbonnier et al., 1999; Schmuth et al., 2002; Gombert et al., 2005; Keller dot blot/lHC et al., 2005; Kim et al., 2007) $\mathrm{PCR} / \mathrm{IHC}$ AD (Nakayama et al., 2001; Schmuth et al., 2002); sensitized ACD patients (Meller et al., 2007)

IHC Behcets and AGEP (Keller et al., 2005)

PCR Mycosis fungoides; cutaneous GvHD (Schmuth et al., 2002)

IHC/IF Langerhans cell histiocytosis (Annels et al., 2003; Fleming et al., 2003)

PCR Lesions of lyme borreliosis (Mullegger et al., 2007)

PCR/IHC Drug-induced maculopapular exanthema (Fernandez et al., 2008)

CCL27 CCR10 Steady state

PCR/Northern/

IHC

Tissue culture Microarray/IF

Primary basal keratinocytes (Morales et al., 1999; Homey et al., 2000, 2002; Humphreys et al., 2005; Meller et al., 2005)

PCR

Podoplanin-low dermal lymphatic EC Mick et al., 2008)

$\begin{array}{cc} & \text { PCR } \\ \text { Inflamed } \quad \text { IHC }\end{array}$

Generally induced by IL-1 $\beta$ and TNF- $\alpha$; inhibited by prostaglandin E2 (Homey et al., 2000, 2002; Kanda et al., 2004; Meller et al., 2005)

PCR/IHC Drug-induced maculopapular exanthema (Tapia et al., 2004; Fernandez et al., 2008)

PCR Skin lesions of systemic sclerosis (Hayakawa et al., 2005)

IHC Cutaneous lupus erythematosus (Meller et al., 2005)

IHC Skin-affected GvHD (Faaij et al., 2006)

microarray/lHC Infections (Haemophilus ducreyi; Staphylococcus aureus; Humphreys et al., 2005; Holland et al., 2009)

PCR ATLL skin lesions (Harasawa et al., 2006)

PCR/lHC Malignant skin tumors (Kai et al., 2011); not confirmed in (Pivarcsi et al., 2007) 
Table 1 | Continued

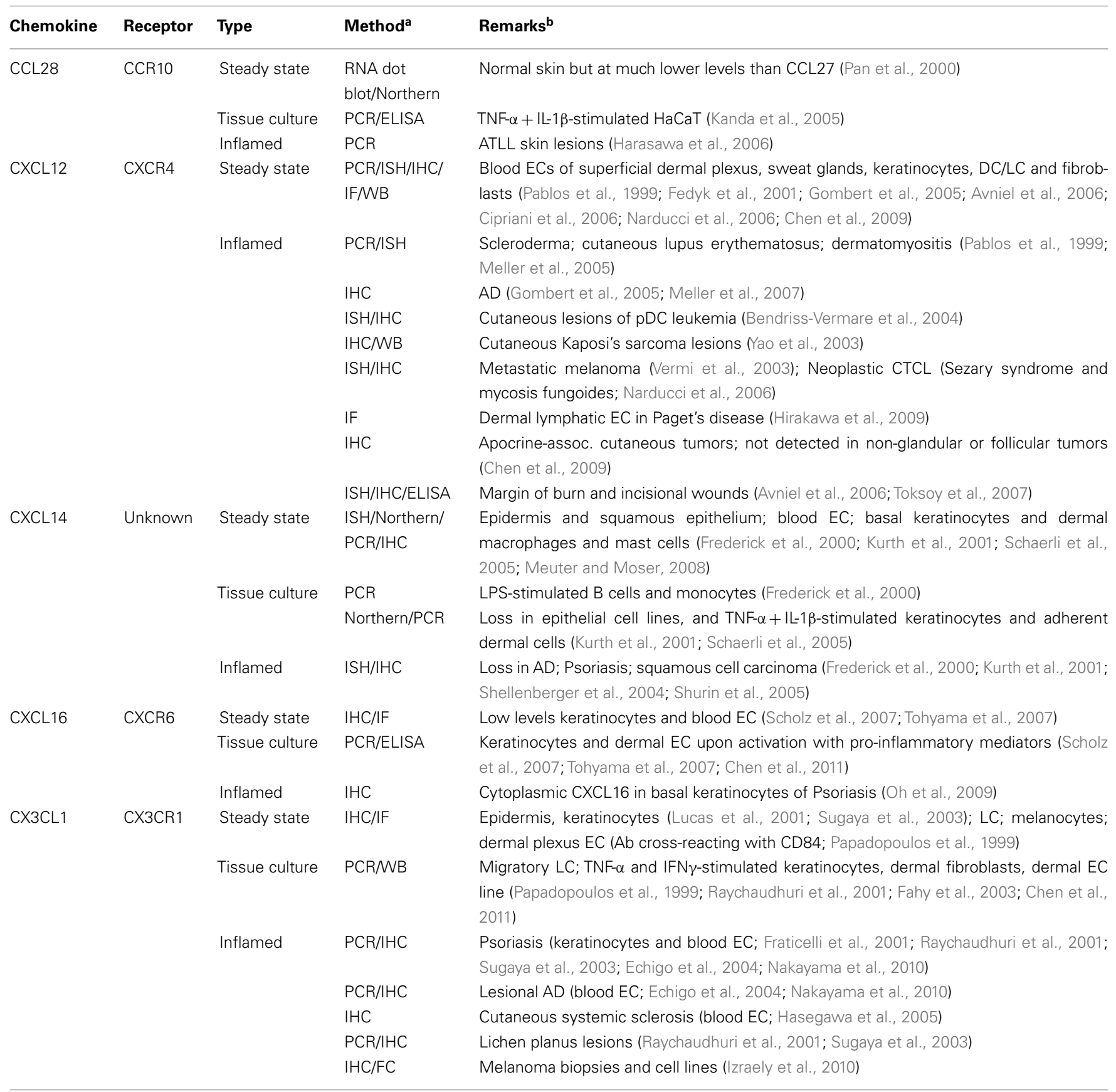

${ }^{a}$ Abbreviations: IHC, immunohistochemistry; IF, immunofluorescence; ISH, in situ hybridization; FC, flow cytometry; RNase PA, RNase protection assay; WB, Western blot.

${ }^{b}$ Abbreviations: $A D$, atopic dermatitis; $A C D$, allergic contact dermatitis; AGEP, acute generalized exanthematous pustulosis; ATLL, adult T-cell leukemia/lymphoma; CTCL, cutaneous T-cell lymphoma; EC, endothelial cells; GVHD, graft versus host disease; LC, Langerhans cells; LPS, lipopolysaccharide; pDC, plasmacytoid dendritic cell; SAg, superantigen; TLR, Toll-like receptor.

epidermal keratinocytes and dermal fibroblasts in response to inflammatory signals (Vestergaard et al., 2000; Albanesi et al., 2001; Horikawa et al., 2002; Fukuda et al., 2003), and are prominently associated with atopic dermatitis (Vestergaard et al., 2000; Goebeler et al., 2001; D’Ambrosio et al., 2002; Horikawa et al.,
2002; Sebastiani et al., 2002; Uchida et al., 2002; Zheng et al., 2003; Echigo et al., 2004; Guttman-Yassky et al., 2007; Gros et al., 2009; Kamsteeg et al., 2010), Psoriasis (Rottman et al., 2001), and cutaneous lymphomas (Ferenczi et al., 2002; Yoshie et al., 2002; Kakinuma et al., 2003b; Ishida et al., 2005). In 
addition to skin, CCL17/22 have been detected at elevated levels in the lung mucosa of asthmatics (Panina-Bordignon et al., 2001; Bochner et al., 2003). Additionally, CCR $4^{+}$T cells have been identified in inflammatory conditions affecting the synovium (Leipe et al., 2010), lung (Panina-Bordignon et al., 2001; Nouri-Aria et al., 2002; Vijayanand et al., 2010), liver (Oo et al., 2010), peritoneum and appendix (Michelle L. McCully and Bernhard Moser, unpublished observations), indicating that CCR4 aids the non-selective migration of effectors to many inflamed sites. In mice, early studies implicated CCR4 as being critical for the migration of antigen-specific effector cells and Tregs to inflamed skin (Reiss et al., 2001; Campbell et al., 2007), but more recent studies found that skin inflammatory responses were intact or even elevated in the absence of CCR4 expression (Lehtimaki et al., 2010; Sells and Hwang, 2010) underlining the significant amount of redundancy in the chemokine network during inflammation.

Similar to CCL17 (see above), CCL20, the single ligand of CCR6, is barely detectable in healthy skin but increases substantially with inflammation (Charbonnier et al., 1999; Homey et al., 2000; Schmuth et al., 2002). Increased CCL20 expression has been detected in several cutaneous inflammatory disorders (Table 1), notably Psoriasis (Charbonnier et al., 1999; Schmuth et al., 2002; Gombert et al., 2005; Keller et al., 2005; Kim et al., 2007). Relevant to the present discussion, CCL20 (as well as CCL17), have been detected at low levels in normal skin. CCL20 expression in the epidermis and on lymphatic endothelium has been proposed to regulate the constitutive migration of CCR $6^{+} \mathrm{LCs}$ and DC precursors (Charbonnier et al., 1999) whereas CCL17 expression in dermal blood vessels was suggested to facilitate trans-endothelial migration of circulating CCR $4^{+}$cells (Campbell et al., 1999; Chong et al., 2004).

A prominent role for CXCL12 in skin-selective homing of immune cells is unlikely due to its ubiquitous tissue distribution and the fact that its specific receptor CXCR4 is expressed on all circulating leukocytes. Evidence for a role of the membranebound chemoattractant CXCL16, the single ligand for CXCR6, in human skin immunity is relatively recent and includes constitutive expression on keratinocytes, and blood endothelia (Scholz et al., 2007; Tohyama et al., 2007). However, its expression is substantially increased in response to pro-inflammatory stimuli and, in addition to skin, CXCL16 is found in healthy lung parenchyma as well as inflammatory sites within the lung (Morgan et al., 2005), liver (Heydtmann et al., 2005), and colon (Diegelmann et al., 2010), precluding its involvement in tissueselective homing. A second membrane-bound chemoattractant, $\mathrm{CX}_{3} \mathrm{CL} 1$, the single ligand for $\mathrm{CX}_{3} \mathrm{CR} 1$, was originally found in the epidermis (Papadopoulos et al., 1999; Sugaya et al., 2003); however, using a more selective antibody reagent, expression of $\mathrm{CX}_{3} \mathrm{CL} 1$ in healthy skin could not be confirmed (Lucas et al., 2001; Echigo et al., 2004), whereas its expression was readily detected in many cutaneous inflammatory lesions (Fraticelli et al., 2001; Raychaudhuri et al., 2001; Sugaya et al., 2003; Echigo et al., 2004; Hasegawa et al., 2005; Izraely et al., 2010; Nakayama et al., 2010).

This leaves three potential chemokine candidates, CCL27, CCL1, and CXCL14, for regulating the trafficking of skin-homing lymphocytes. CCL27 is selectively produced by epidermal keratinocytes and controls the migration of CCR $10^{+} \mathrm{T}$ cells to the epidermal compartment (Morales et al., 1999; Sigmundsdottir et al., 2007). In blood of healthy donors, CCR $10^{+} \mathrm{T}$ cells make up a significant proportion of CLA ${ }^{+} \mathrm{T}$ cells (Hudak et al., 2002), whereas in healthy skin, CCR $10^{+}$cells were not detected (Michelle L. McCully and Bernhard Moser, unpublished observations), arguing against a role for CCL27 in controlling cutaneous T cell traffic under steady-state conditions. Epidermal CCL27 production is significantly increased in response to inflammatory mediators and is prominently present in cutaneous inflammatory lesions (listed in Table 1). In support of an inflammatory role, CCL27-CCR10 was found to regulate $\mathrm{T}$ cell recruitment to the epidermis in mouse models of acute skin inflammation (Reiss et al., 2001; Homey et al., 2002). Of interest, CCR $10^{+}$cells are also targeted by CCL28, which is widely expressed by many mucosal tissues (Pan et al., 2000), which were shown to harbor CCR10 ${ }^{+} \mathrm{T}$ cells, and B cells (Eksteen et al., 2006; Morteau et al., 2008), arguing against a contribution to a skin-selective address code.

CXCL14 and CCL1 are two chemokines that are readily detected in healthy human skin. CCL1 and its receptor CCR8 are discussed separately in the next chapter. CXCL14 is constitutively expressed in epidermal and squamous epithelial tissues (Meuter and Moser, 2008). In skin, CXCL14 is mainly produced by basal keratinocytes, but expression has also been detected on dermal endothelial cells, macrophages, and mast cells (Kurth et al., 2001; Schaerli et al., 2005; Meuter and Moser, 2008). Of note, the production of this chemokine by keratinocytes was very high, allowing for its purification from natural sources in quantities large enough for functional studies. The receptor for CXCL14 has yet to be identified, but chemotaxis assays have implicated CXCL14 in the specific mobilization of monocytes (Kurth et al., 2001), NK cells (Starnes et al., 2006), and human, but not mouse, dendritic cell precursors (Schaerli et al., 2005; Starnes et al., 2006; Meuter et al., 2007). CXCL14 does not act on T cells and, therefore, does not play a role in controlling immune surveillance $\mathrm{T}$ cells in healthy human skin. Numerous additional inflammatory chemokines not listed in Table 1 are also known to be produced in diseased skin, but have been excluded here as they are known to be produced in many other inflamed tissues and thus, cannot account for skin-specific immune cell traffic.

\section{DOES CCL1-CCR8 PLAY A ROLE IN SKIN IMIMUNITY?}

Today, CCL1-CCR8 is one of the least understood chemokine system despite the fact that CCL1 (formerly known as I-309 and TCA3 in human and mouse, respectively) was the first among a long succession of CC chemokines to be discovered (Burd et al., 1987; Miller et al., 1989). The cDNA cloning strategy, based on RNA extracted from human and mouse $\mathrm{T}$ cells, already indicated that CCL1 may target T cells; and activated $\mathrm{T}$ cells secrete up to large amounts of CCL1, whereas its production by tissue cells appears to be less prominent (Table 2). CCL1 is not a bona fide inflammatory chemokine since its expression in the presence of inflammatory stimuli is controversial. Besides activated $\mathrm{T}$ cells, human immune cells reported to produce CCL1 mRNA, and/or protein include mast cells and DCs. In skin, CCL1 is produced by cultured T cells 
Table 2 | Expression of human CCL1 and CCR8.

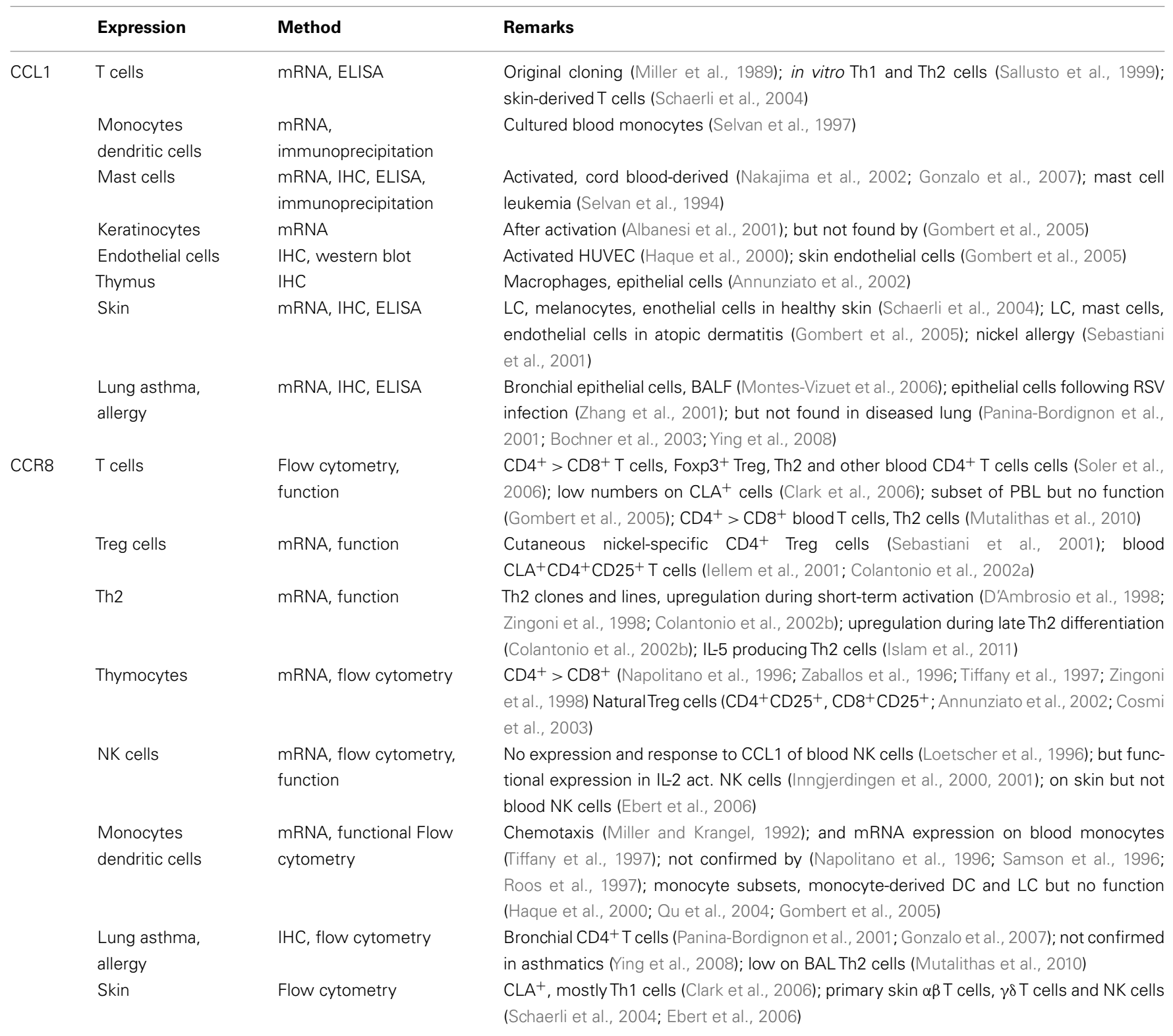

as well as LCs, possibly melanocytes and microvascular endothelial cells but not by keratinocytes or dermal fibroblasts (Schaerli et al., 2004). Its expression was also associated with atopic dermatitis, allergy, and asthma (Sebastiani et al., 2001; Zhang et al., 2001; Gombert et al., 2005; Montes-Vizuet et al., 2006) although this finding could not be confirmed by others (Panina-Bordignon et al., 2001; Bochner et al., 2003; Ying et al., 2008). There is no evidence for CCL1 production by other tissues. Obviously, identification of CCL1 target cells is of paramount importance for understanding the role played by CCL1 in physiologic and/or pathologic conditions.

CCR8, the only receptor for CCL1, was cloned in the late 90s (Roos et al., 1997; Tiffany et al., 1997; Goya et al., 1998). Early mRNA expression and functional data pointed to CCR8 being expressed by diverse subsets of T cells, including Th1, Th2, Treg cells, and, interestingly, $\mathrm{CD} 4^{+} \mathrm{CD} 25^{\mathrm{hi}}$ thymocytes with natural Treg function (Table 2). Expression and function of CCR8 in monocytes, DCs, and NK cells is still controversial and this is most likely due to paucity in CCR8-specific Abs. Some commercial Abs turned out to lack specificity or showed cross-reactivity with several chemokine receptors, which added to the confusion about the CCL1 target cells.

Mice with genetic modifications provide strong models for the in vivo study of chemokine systems. TCA3, the mouse orthologue of human CCL1, was originally cloned from activated T cells (Burd et al., 1987) and its receptor CCR8 was found to be expressed by lymphocytes from blood and thymus (Zaballos et al., 1996; Goya et al., 1998). The results from CCR $8^{-/-}$mice are controversial. 
Two studies demonstrate a role for CCR8 in the control of Th2 cells and eosinophils in models of allergic lung diseases (Chensue et al., 2001; Gonzalo et al., 2007), implicating mast cells as a source of CCL1. However, these findings were contested by the work of other laboratories (Chung et al., 2003; Goya et al., 2003; Mikhak et al., 2009). Although a role for CCR8 in antigen-driven lung disease remains unclear, an additional study has implicated CCR8 in contributing to the development of chronic inflammation in a model of chronic Aspergillus-induced asthma (Buckland et al., 2007). A separate line of studies has linked CCR8 signaling with protection of apoptosis in mouse thymocytes (Van Snick et al., 1996; Louahed et al., 2003; Spinetti et al., 2003), suggesting a role in thymocyte development (Kremer et al., 2001). A recent report highlights the importance of CCR8 in a mouse model of atopic dermatitis (Islam et al., 2011). However, it is important to note that in this model mouse CCL8, but not mouse CCL1, was identified as the physiologically relevant ligand for CCR8 involved in controlling Th2 mobilization, and subsequent skin allergy development. To complicate matters further, human CCL8 (alias MCP-2), one of four chemokines for CCR2, does not bind to human or mouse CCR8, highlighting fundamental differences in immune mechanisms between mice and humans. Collectively, mouse CCR 8 marks a subset of Th2 cells with a potential role in allergic disease of lung and skin and, probably, a subset of thymic $\mathrm{CD}^{+}{ }^{+} \mathrm{T}$ cells. An involvement of CCL1/CCL8 and CCR8 in gastrointestinal inflammation has not been reported.

The current state in research supports our view that CCR8 marks a functionally heterogeneous population of $\mathrm{CD}^{+}$and $\mathrm{CD}^{+} \mathrm{T}$ cells subsets featuring homing preferences for human skin (although lung homing properties cannot be excluded at present; Figure 2). Human skin is a vast reservoir for memory T cells under steady-state conditions, most of which express CCR8 (Table 3). Our previous work found that the majority of skin-resident $\mathrm{CD} 4^{+}$ and $\mathrm{CD}^{+} \alpha \beta \mathrm{T}$ cells, $\left(\mathrm{V} \delta 1^{+}\right) \gamma \delta \mathrm{T}$ cells, and a subset NK cells stained positive for this receptor (Schaerli et al., 2004; Ebert et al., 2006). Several reports have documented CCR8 expression on skin LCs, DCs, and their mononuclear precursors (Haque et al., 2000; Qu et al., 2004; Gombert et al., 2005; Gros et al., 2009), but we were unable to confirm these findings.

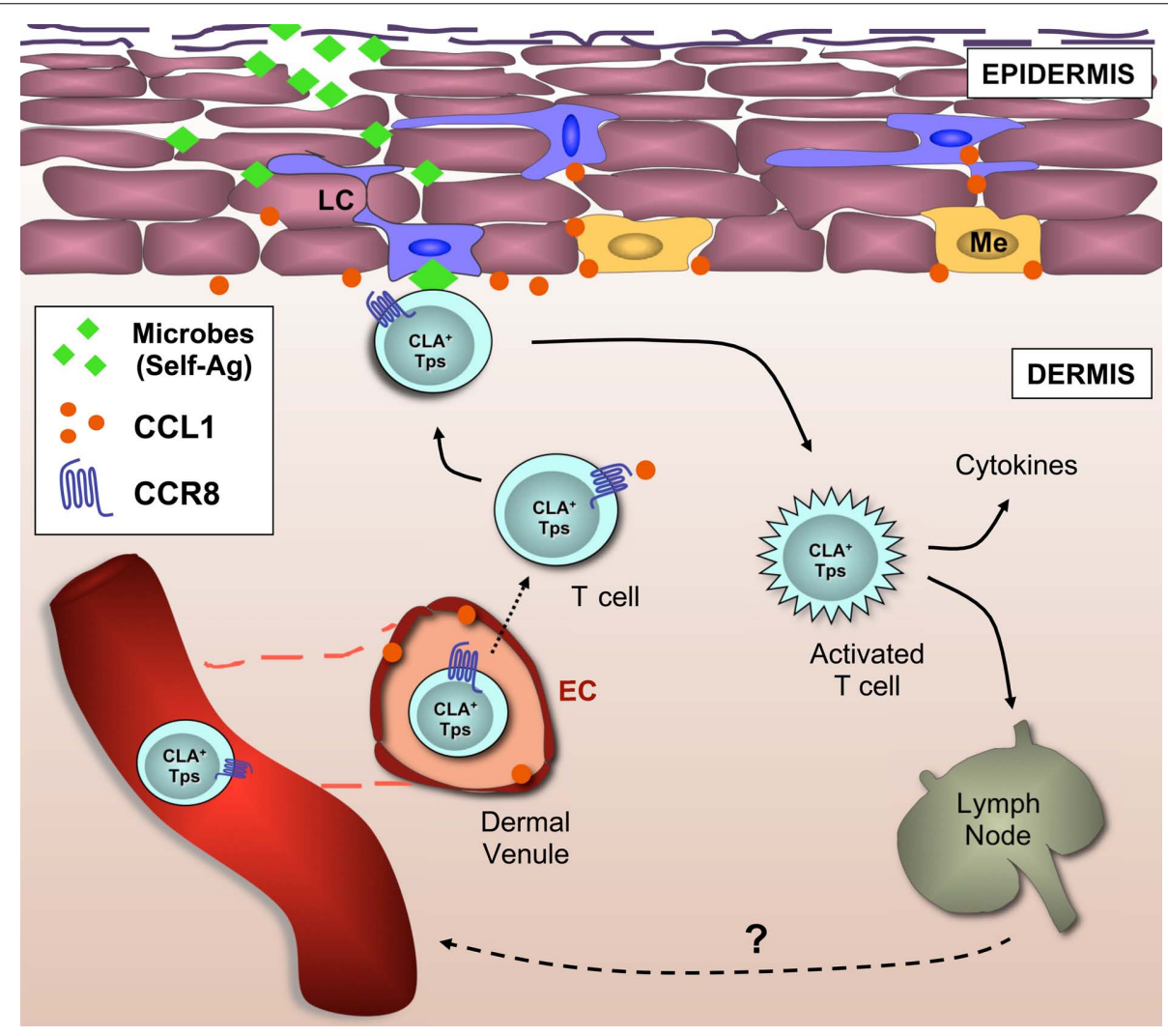

FIGURE 2 | CCR8 ${ }^{+}$T cells are part of the cellular immune surveillance system in healthy human skin. This model describes the recruitment to the skin and retention of $\mathrm{CCR}^{+}$memory T cells (and possibly NK cells). The skin address code is composed of CLA, a ligand for E/P-selectins, and CCR8, the chemokine receptor for CCL1, both present on the luminal side of the microvasculature within the dermal plexus. Following trans-endothelial migration, dermal CCR8 ${ }^{+} \mathrm{T}$ cells sense CCL1 constitutively expressed by LCs (and possibly melanocytes), and subsequent co-localization allows the screening of LCs by CCR8 ${ }^{+} \mathrm{T}$ cells for the presence of cognate peptide-MHC molecules. Self-peptide-presenting LCs may induce local Treg cell responses whereas microbial peptide-presenting LCs may induce protective anti-microbial T cell responses. In this model, CCR8 does not distinguish between functional $T$ cell subsets, but rather combines different $T$ cell subsets that are necessary for immune surveillance of human skin in the steady state. Tps, peripheral surveillance T cell; EC, endothelial cell; Me, melanocyte; LC, Langerhans cell; CLA, cutaneous T lymphocyte antigen. 
Table 3 | CCR8 in cutaneous immune cells.

\begin{tabular}{llll}
\hline Cell type & $\begin{array}{l}\text { Steady } \\
\text { state }\end{array}$ & $\begin{array}{l}\text { Range } \\
\mathbf{( \% )}\end{array}$ & Reference \\
\hline LYMPHOCYTES & & & \\
CD3 ${ }^{+}$T cells & + & $\left(46-54^{*}\right)$ & Clark et al. (2006) \\
CD4 ${ }^{+}$T cells & + & $(36-74)$ & Schaerli et al. (2004) \\
CD8 ${ }^{+}$T cells & + & $(59-95)$ & Schaerli et al. (2004) \\
$\gamma \delta$ T cells & + & $(46-60)$ & Ebert et al. (2006) \\
B cells & - & & Schaerli et al. (2004) \\
NON-LYMPHOCYTES & & & \\
NK cells & + & $(<50)$ & Ebert et al. (2006) \\
Monocytes/macrophages & - & & Schaerli et al. (2004) \\
DCs & - & & Schaerli et al. (2004) \\
\hline
\end{tabular}

${ }^{*}$ Combined ranges from all isolation techniques.

Despite being coined a marker for Th2 cells, CCR8-expressing, skin-derived $\mathrm{CD}^{+}$, and $\mathrm{CD}^{+}{ }^{+} \mathrm{T}$ cells were biased toward the production of the pro-inflammatory cytokines IFN $\gamma, \mathrm{TNF} \alpha$, and IL-2 after ex vivo stimulation, while the secretion of Th2-associated cytokines (IL-4, IL-5, and IL-13) were rarely detected (Schaerli et al., 2004; Clark et al., 2006). Additionally, CCR8-expressing $\mathrm{CD}^{+} \mathrm{T}$ cells were devoid of cytolytic functions, suggesting that $\mathrm{CCR}^{+}{ }^{+} \mathrm{T}$ cells participate in local immune responses through the secretion of pro-inflammatory cytokines. The fact that skin-tropic viruses encode functional proteins targeting CCR8 further supports a role of CCR8 in skin-specific immune defense. Specifically, the human poxvirus molluscum contagiosum encodes a selective antagonist for CCR8, called MC148 (Luttichau et al., 2000). And human herpes virus 8 (HHV8) encodes two viral orthologues of the macrophage inflammatory protein family (vMIP-I and vMIPII); vMIP-I functions as a CCR8 agonist, while vMIP-II serves as a broad-spectrum chemokine receptor antagonist (Sozzani et al., 1998; Dairaghi et al., 1999; Endres et al., 1999).

Although CCR8 marked a significant proportion of skinresident $\mathrm{T}$ cells in the steady state, $\mathrm{CCR} 8^{+}$cells were at present not found (or were extremely rare) in many skin-associated inflammatory diseases (Schaerli et al., 2004; Gombert et al., 2005; Keller et al., 2005; Ottaviani et al., 2006; Gros et al., 2009). The relevance of this disparate expression (non-inflamed versus inflamed) is currently unclear but points toward a role for CCR8 and its ligand CCL1 in the localization of peripheral $\mathrm{T}$ cells and NK cells under steady-state conditions. This is supported by the presence of CCL1 expression on the dermal microvasculature as well as by epidermal Langerhans cells and melanocytes of healthy, non-inflamed, human skin. Importantly, we did not find CCL1 expression in keratinocytes or dermal fibroblasts; two cell types that mainly produce CXCL14 in the steady state and a multitude of inflammatory chemokines in response to infection. Based on these data, we propose a model whereby CCL1-CCR8 regulates the homeostatic homing of peripheral immune-surveillance $\mathrm{T}$ cells to human skin tissue (Figure 2 ). This model predicts that the presence of low levels of CCL1 on microvascular endothelial cells recruits $\mathrm{CLA}^{+} \mathrm{CCR}^{+} \mathrm{T}$ cells to the dermis of healthy human skin. Expression of CCL1 by LCs and/or melanocytes may localize dermal CCR ${ }^{+}{ }^{+}$cells in close proximity of the epidermis. In fact, CCL1 production by LCs as opposed to the highly abundant keratinocytes (or dermal fibroblasts) fits nicely with the view of a continuous interaction between CCL1-responding memory $\mathrm{T}$ cells in the dermis and peptide-MHC-presenting LCs in the epidermis. By responding to self-peptide-MHC or microbial peptide-MHC molecules, dermal CCR $8^{+} \mathrm{T}$ cells would act as essential players in tissue homeostasis, and/or anti-microbial immunity. This model also extends to cutaneous $\gamma \delta \mathrm{T}$ cells and even NK cells, indicating that the principal role of CCL1CCR8 may be to regulate the co-localization of immune surveillance cells in healthy skin that, collectively, guarantee skin tissue integrity.

\section{CONCLUDING REMARKS}

As discussed above, we propose that the single chemokine, CCL1, and its receptor CCR8 regulate the steady-state homing of longlived lymphocyte populations to human skin tissue. The relationship between CCR $8^{+} \mathrm{T}$ cells in the skin and those in blood is not clear at present. However, we would like to portray the view that they differ fundamentally in terms of function. In support, in a mouse model of cutaneous HSV infection, HSV-specific memory T cells were shown to reside primarily in skin tissue as opposed to blood (Wakim et al., 2008; Gebhardt et al., 2009). Although similar studies cannot be done in humans, we, and others have shown that human skin-derived CCR $8^{+}$T cells are capable of producing many cytokines in response to stimulation with a bias toward the production of Th1 cytokines (Schaerli et al., 2004; Clark et al., 2006). On the other hand, blood CCR $8^{+} \mathrm{T}$ cells preferentially secrete Th2 type cytokines (Zingoni et al., 1998; Soler et al., 2006; Islam et al., 2011), most notably IL-5 (Zingoni et al., 1998; Soler et al., 2006; Islam et al., 2011). Furthermore, we wish to point out that in addition to $\alpha \beta$ T cells, NK cells, and $\gamma \delta$ T cells in healthy human skin also express CCR8, further underscoring the heterogeneity among $\mathrm{CCR}^{+}{ }^{+}$cells. Clearly, further studies with primary lymphocytes from human skin are required to better define their function. It is essential that these studies be carried out using human tissue as mouse skin differs fundamentally from human in terms of physiology (i.e., fur, thickness, vitamin metabolism) as well as in the types of immune cells present (DETC cells in mice that are absent in humans). These studies also need to include experiments focusing on the generation of $\mathrm{CCR} 8^{+} \mathrm{T}$ cells during activation of naïve peripheral blood $\mathrm{T}$ cells with diverse subsets of DCs as the factors that induce CCR8 expression in T cells have yet to be defined. What does appear to be certain at this stage is that there exists significant phenotypic and functional heterogeneity among human skin CCR $8^{+}$lymphocytes, lending support to the model whereby CCR8 marks immune surveillance cells characterized by a distinct tissue tropism (skin) as opposed to a specific effector function.

\section{ACKNOWLEDGMENTS}

In this review, we have focused on citing human research and due to space limitations were unable to include an extensive list of references pertaining to non-human research. Research has been supported by a grant from the Wellcome Trust; B.M. is the recipient of a Royal Society Wolfson Research Merit Award. 


\section{REFERENCES}

Agace, W. W. (2008). T-cell recruitment to the intestinal mucosa. Trends Immunol. 29, 514-522.

Albanesi, C., Scarponi, C., Sebastiani, S., Cavani, A., Federici, M., Sozzani, S., and Girolomoni, G. (2001). A cytokine-to-chemokine axis between Tlymphocytes and keratinocytes can favor Thl cell accumulation in chronic inflammatory skin diseases. J. Leukoc. Biol. 70, 617-623.

Annels, N. E., Da Costa, C. E., Prins, F. A., Willemze, A., Hogendoorn, P. C., and Egeler, R. M. (2003). Aberrant chemokine receptor expression and chemokine production by Langerhans cells underlies the pathogenesis of Langerhans cell histiocytosis. J. Exp. Med. 197, 1385-1390.

Annunziato, F., Cosmi, L., Liotta, F., Lazzeri, E., Manetti, R., Vanini, V., Romagnani, P., Maggi, E., and Romagnani, S. (2002). Phenotype, localization, and mechanism of suppression of $\mathrm{CD} 4(+) \mathrm{CD} 25(+)$ human thymocytes. J. Exp. Med. 196, 379-387.

Avniel, S., Arik, Z., Maly, A., Sagie, A., Basst, H. B., Yahana, M. D., Weiss, I. D., Pal, B., Wald, O., AdEl, D., Fujii, N., Arenzana-Seisdedos, F., Jung, S., Galun, E., Gur, E., and Peled, A. (2006). Involvement of the CXCL12/CXCR4 pathway in the recovery of skin following burns. $J$. Invest. Dermatol. 126, 468-476.

Bendriss-Vermare, N., Chaperot, L., Peoc'h, M., Vanbervliet, B., Jacob, M. C., Briere, F., Bensa, J. C., Caux, C., and Plumas, J. (2004). In situ leukemic plasmacytoid dendritic cells pattern of chemokine receptors expression and in vitro migratory response. Leukemia 18, 1491-1498.

Bochner, B. S., Hudson, S. A., Xiao, H. Q., and Liu, M. C. (2003). Release of both CCR4-active and CXCR3active chemokines during human allergic pulmonary late-phase reactions. J. Allergy Clin. Immunol. 112, 930-934.

Brinkman, C. C., Sheasley-O’Neill, S. L., Ferguson, A. R., and Engelhard, V. H. (2008). Activated CD8 T cells redistribute to antigen-free lymph nodes and exhibit effector and memory characteristics. J. Immunol. 181, 1814-1824.

Buckland, K.F., O'connor, E. C., Coleman, E. M., Lira, S. A., Lukacs, N. W., and Hogaboam, C. M. (2007). Remission of chronic fungal asthma in the absence of CCR8. J. Allergy Clin. Immunol. 119, 997-1004.

Burd, P.R., Freeman, G. J., Wilson, S. D., Berman, M., DeKruyff, R., Billings, P.
R., and Dorf, M. E. (1987). Cloning and characterization of a novel $\mathrm{T}$ cell activation gene. J. Immunol. 139, 3126-3131.

Campanati, A., Goteri, G., Simonetti, O., Ganzetti, G., Giuliodori, K., Stramazzotti, D., Morichetti, D., Bernardini, M. L., Mannello, B., Fabris, G., and Offidani, A. (2007). CTACK/CCL27 expression in psoriatic skin and its modification after administration of etanercept. $\mathrm{Br}$. J. Dermatol. 157, 1155-1160.

Campbell, J. J., Haraldsen, G., Pan, J., Rottman, J., Qin, S., Ponath, P., Andrew, D. P., Warnke, R., Ruffing, N., Kassam, N., Wu, L., and Butcher, E. C. (1999). The chemokine receptor CCR4 in vascular recognition by cutaneous but not intestinal memory T cells. Nature 400, 776-780.

Campbell, J. J., O'Connell, D. J., and Wurbel, M. A. (2007). Cutting edge: chemokine receptor CCR4 is necessary for antigen-driven cutaneous accumulation of CD4 T cells under physiological conditions. J. Immunol. 178, 3358-3362.

Charbonnier, A. S., Kohrgruber, N., Kriehuber, E., Stingl, G., Rot, A., and Maurer, D. (1999). Macrophage inflammatory protein 3alpha is involved in the constitutive trafficking of epidermal langerhans cells. $J$. Exp. Med. 190, 1755-1768.

Chen, S.J., Nakahara, T., Kido, M., Takahara, M., Uchi, H., Takeuchi, S., Dugu, L., Tu, Y. T., Moroi, Y., Furue, M. (2009). Stromal cellderived factor 1 expression in various skin tumours. Br. J. Dermatol. 160, 710-713.

Chen, T., Guo, Z. P., Jiao, X. Y., Jia, R. Z., Zhang, Y. H., Li, J. Y., Huang, X. L., and Liu, H. J. (2011). Peoniflorin suppresses tumor necrosis factoralpha induced chemokine production in human dermal microvascular endothelial cells by blocking nuclear factor-kappaB and ERK pathway. Arch. Dermatol. Res. 303, 351-360.

Chensue, S.W., Lukacs, N. W., Yang, T. Y., Shang, X., Frait, K. A., Kunkel, S. L., Kung, T., Wiekowski, M. T., Hedrick, J. A., Cook, D. N., Zingoni, A., Narula, S. K., Zlotnik, A., Barrat, F. J., O'Garra, A., Napolitano, M., and Lira, S. A. (2001). Aberrant in vivo $\mathrm{T}$ helper type 2 cell response and impaired eosinophil recruitment in CC chemokine receptor 8 knockout mice. J. Exp. Med. 193, 573-584.

Chong, B. F., Murphy, J. E., Kupper, T. S., and Fuhlbrigge, R. C. (2004). E-selectin, thymus- and activationregulated chemokine/CCL17, and intercellular adhesion molecule-1 are constitutively coexpressed in dermal microvessels: a foundation for a cutaneous immunosurveillance system. J. Immunol. 172, 1575-1581.

Chung, C. D., Kuo, F., Kumer, J., Motani, A. S., Lawrence, C. E., Henderson, W. R. Jr., and Venkataraman, C. (2003). CCR8 is not essential for the development of inflammation in a mouse model of allergic airway disease. $J$. Immunol. 170, 581-587.

Cipriani, P., Franca Milia, A., Liakouli, V., Pacini, A., Manetti, M., Marrelli, A., Toscano, A., Pingiotti, E., Fulminis, A., Guiducci, S., Perricone, R., Kahaleh, B., Matucci-Cerinic, M., Ibba-Manneschi, L., and Giacomelli, R. (2006). Differential expression of stromal cell-derived factor 1 and its receptor CXCR4 in the skin and endothelial cells of systemic sclerosis patients: pathogenetic implications. Arthritis Rheum. 54, 3022-3033.

Clark, R.A., Chong, B., Mirchandani, N., Brinster, N. K., Yamanaka, K., Dowgiert, R. K., and Kupper, T. S. (2006). The vast majority of CLA+ $\mathrm{T}$ cells are resident in normal skin. $J$. Immunol. 176, 4431-4439.

Colantonio, L., Iellem, A., Sinigaglia, F., and D'Ambrosio, D. (2002a). Skinhoming CLA+ $\mathrm{T}$ cells and regulatory CD25+ $\mathrm{T}$ cells represent major subsets of human peripheral blood memory $\mathrm{T}$ cells migrating in response to CCL1/I-309. Eur. J. Immunol. 32, 3506-3514.

Colantonio, L., Recalde, H., Sinigaglia, F., and D'Ambrosio, D. (2002b). Modulation of chemokine receptor expression and chemotactic responsiveness during differentiation of human naive T cells into Th1 or Th2 cells. Eur. J. Immunol. 32, 1264-1273.

Coombes, J. L., and Siddiqui, K. R. Arancibia-Cárcamo, C. V., Hall, J., Sun, C. M., Belkaid, Y., and Powrie, F. (2007). A functionally specialized population of mucosal CD103 DCs induces Foxp3 regulatory T cells via a TGF-beta and retinoic aciddependent mechanism. J. Exp. Med. 204, 1757-1764.

Cosmi, L., Liotta, F., Lazzeri, E., Francalanci, M., Angeli, R., Mazzinghi, B., Santarlasci, V., Manetti, R., Vanini, V., Romagnani, P., Maggi, E., Romagnani, S., and Annunziato, F. (2003). Human CD8+ CD25+ thymocytes share phenotypic and functional features with CD4+ CD25+ regulatory thymocytes. Blood 102, 4107-4114.

D’Ambrosio, D., Albanesi, C., Lang, R., Girolomoni, G., Sinigaglia, F., and Laudanna, C. (2002). Quantitative differences in chemokine receptor engagement generate diversity in integrin-dependent lymphocyte adhesion. J. Immunol. 169 , 2303-2312.
D’Ambrosio, D., Iellem, A., Bonecchi, R., Mazzeo, D., Sozzani, S., Mantovani, A., and Sinigaglia, F. (1998). Selective up-regulation of chemokine receptors CCR4 and CCR8 upon activation of polarized human type $2 \mathrm{Th}$ cells. J. Immunol. 161, 5111-5115.

Dairaghi, D.J., Fan, R. A., McMaster, B. E., Hanley, M. R., and Schall, T. J. (1999). HHV8-encoded vMIPI selectively engages chemokine receptor CCR8. Agonist and antagonist profiles of viral chemokines. $J$. Biol. Chem. 274, 21569-21574.

del Rio, M. L., Bernhardt, G., RodriguezBarbosa, J. I., and Förster, R. (2010). Development and functional specialization of CD103 dendritic cells. Immunol. Rev. 234, 268-281.

Diegelmann, J., Seiderer, J., Niess, J. H., Haller, D., Göke, B., Reinecker, H. C., and Brand, S. (2010). Expression and regulation of the chemokine CXCL16 in Crohn's disease and models of intestinal inflammation. Inflamm. Bowel Dis. 16, 1871-1881.

Dieu-Nosjean, M. C., Massacrier, C., Homey, B., Vanbervliet, B., Pin, J. J., Vicari, A., Lebecque, S., DezutterDambuyant, C., Schmitt, D., Zlotnik, A., and Caux, C. (2000) Macrophage inflammatory protein 3alpha is expressed at inflamed epithelial surfaces and is the most potent chemokine known in attracting Langerhans cell precursors. J. Exp. Med. 192, 705-718.

Dudda, J. C., Lembo, A., Bachtanian, E., Huehn, J., Siewert, C., Hamann, A., Kremmer, E., Förster, R., and Martin, S. F. (2005). Dendritic cells govern induction and reprogramming of polarized tissue-selective homing receptor patterns of T cells: important roles for soluble factors and tissue microenvironments. Eur. J. Immunol. 35, 1056-1065.

Ebert, L. M., Meuter, S., and Moser, B. (2006). Homing and function of human skin gammadelta $\mathrm{T}$ cells and NK cells: relevance for tumor surveillance. J. Immunol. 176, 4331-4336.

Echigo, T., Hasegawa, M., Shimada, Y., Takehara, K., and Sato, S. (2004). Expression of fractalkine and its receptor, CX3CR1, in atopic dermatitis: possible contribution to skin inflammation. J. Allergy Clin. Immunol. 113, 940-948.

Edele, F., Molenaar, R., Gütle, D., Dudda, J. C., Jakob, T., Homey, B., Mebius, R., Hornef, M., and Martin, S. F. (2008). Cutting edge: instructive role of peripheral tissue cells in the imprinting of $\mathrm{T}$ cell homing receptor patterns. J. Immunol. 181, 3745-3749. 
Eksteen, B., Miles, A., Curbishley, S. M., Tselepis, C., Grant, A. J., Walker, L. S., and Adams, D. H. (2006). Epithelial inflammation is associated with CCL28 production and the recruitment of regulatory $\mathrm{T}$ cells expressing CCR10. J. Immunol. 177, 593-603.

Eksteen, B., Mora, J. R., Haughton, E. L., Henderson, N. C., Lee-Turner, L., Villablanca, E. J., Curbishley, S. M., Aspinall, A. I., von Andrian, U. H., and Adams, D. H. (2009). Gut homing receptors on CD8 $\mathrm{T}$ cells are retinoic acid dependent and not maintained by liver dendritic or stellate cells. Gastroenterology 137, 320-329.

Endres, M. J., Garlisi, C. G., Xiao, H., Shan, L., and Hedrick, J. A. (1999). The Kaposi's sarcoma-related herpesvirus (KSHV)-encoded chemokine vMIP-I is a specific agonist for the CC chemokine receptor (CCR)8. J. Exp. Med. 189, 1993-1998.

Faaij, C.M., Lankester, A. C., Spierings, E., Hoogeboom, M., Bowman, E. P., Bierings, M., Révész, T., Egeler, R. M., van Tol, M. J., and Annels, N. E. (2006). A possible role for CCL27/CTACK-CCR10 interaction in recruiting CD4 $\mathrm{T}$ cells to skin in human graft-versus-host disease. $\mathrm{Br}$. J. Haematol. 133, 538-549.

Fahy, O.L., Coates, N. J., and McColl, S. R. (2003). Inhibition of cytokineinduced fractalkine production by bacterial invasion of human-dermal fibroblasts. Lab. Invest. 83, 721-730.

Fedyk, E.R., Jones, D., Critchley, H. O., Phipps, R. P., Blieden, T. M., and Springer, T. A. (2001). Expression of stromal-derived factor- 1 is decreased by IL-1 and TNF and in dermal wound healing. J. Immunol. 166, 5749-5754.

Ferenczi, K., Fuhlbrigge, R. C., Pinkus, J., Pinkus, G. S., and Kupper, T. S. (2002). Increased CCR4 expression in cutaneous $\mathrm{T}$ cell lymphoma. $J$. Invest. Dermatol. 119, 1405-1410.

Fernandez, T. D., Mayorga, C., Torres, M. J., Cornejo-Garcia, J. A., López, S., Chaves, P., Rondon, C., and Blanca, M. (2008). Cytokine and chemokine expression in the skin from patients with maculopapular exanthema to drugs. Allergy 63, 712-719.

Fitzhugh, D. J., Naik, S., Gonzalez, E., Caughman, S. W., and Hwang, S. T. (2000). CC chemokine receptor 6 (CCR6) is a marker for memory $\mathrm{T}$ cells that arrest on activated human dermal microvascular endothelium under shear stress. J. Invest. Dermatol. 115, 332.
Fleming, M. D., Pinkus, J. L., Fournier, M. V., Alexander, S. W., Tam, C., Loda, M., Sallan, S. E., Nichols, K. E., Carpentieri, D. F., Pinkus, G. S., and Rollins, B. J. (2003). Coincident expression of the chemokine receptors CCR6 and CCR7 by pathologic Langerhans cells in Langerhans cell histiocytosis. Blood 101, 2473-2475.

Fraticelli, P., Sironi, M., Bianchi, G., D’Ambrosio, D., Albanesi, C., Stoppacciaro, A., Chieppa, M., Allavena, P., Ruco, L., Girolomoni, G., Sinigaglia, F., Vecchi, A., and Mantovani, A. (2001). Fractalkine (CX3CL1) as an amplification circuit of polarized Th1 responses. J. Clin. Invest. 107, 1173-1181.

Frederick, M. J., Henderson, Y., Xu, X., Deavers, M. T., Sahin, A. A., Wu, H., Lewis, D. E., El-Naggar, A. K., and Clayman, G. L. (2000). In vivo expression of the novel CXC chemokine BRAK in normal and cancerous human tissue. Am. J. Pathol. 156, 1937-1950.

Fukuda, K., Fujitsu, Y., Seki, K., Kumagai, N., and Nishida, T. (2003). Differential expression of thymusand activation-regulated chemokine (CCL17) and macrophage-derived chemokine (CCL22) by human fibroblasts from cornea, skin, and lung. J. Allergy Clin. Immunol. 111, 520-526.

Gebhardt, T., Wakim, L. M., Eidsmo, L., Reading, P. C., Heath, W. R., and Carbone, F. R. (2009). Memory $\mathrm{T}$ cells in nonlymphoid tissue that provide enhanced local immunity during infection with herpes simplex virus. Nat. Immunol. 10, 524-530.

Ghannam, S., Dejou, C., Pedretti, N., Giot, J. P., Dorgham, K., Boukhaddaoui, H., Deleuze, V., Bernard, F. X., Jorgensen, C., Yssel, H., and Pène, J. (2011). CCL20 and beta-defensin-2 induce arrest of human Th17 cells on inflamed endothelium in vitro under flow conditions. J. Immunol. 186, 1411-1420.

Giustizieri, M. L., Albanesi, C., Fluhr, J., Gisondi, P., Norgauer, J., and Girolomoni, G. (2004). H1 histamine receptor mediates inflammatory responses in human keratinocytes. J. Allergy Clin. Immunol. 114, 1176-1182.

Goebeler, M., Trautmann, A., Voss, A., Bröcker, E. V., Toksoy, A., and Gillitzer, R. (2001). Differential and sequential expression of multiple chemokines during elicitation of allergic contact hypersensitivity. Am. J. Pathol. 158, 431-440.
Gombert, M., Dieu-Nosjean, M. C., Winterberg, F., Bünemann, E., Kubitza, R. C., Da Cunha, L., Haahtela, A., Lehtimäki, S., Müller, A., Rieker, J., Meller, S., Pivarcsi, A., Koreck, A., Fridman, W. H., Zentgraf, H. W., Pavenstädt, H., Amara, A., Caux, C., Kemeny, L., Alenius, H., Lauerma, A., Ruzicka, T., Zlotnik, A., and Homey, B. (2005). CCL1-CCR8 interactions: an axis mediating the recruitment of $\mathrm{T}$ cells and Langerhans-type dendritic cells to sites of atopic skin inflammation. J. Immunol. 174, 5082-5091.

Gonzalo, J.A., Qiu, Y., Lora, J. M., AlGarawi, A., Villeval, J. L., Boyce, J. A., Martinez-A, C., Marquez, G., Goya, I., Hamid, Q., Fraser, C. C., Picarella, D., Cote-Sierra, J., Hodge, M. R., Gutierrez-Ramos, J. C., Kolbeck, R., and Coyle, A. J. (2007). Coordinated involvement of mast cells and T cells in allergic mucosal inflammation: critical role of the CC chemokine ligand 1:CCR8 axis. J. Immunol. 179, 1740-1750.

Goya, I., Gutiérrez, J., Varona, R., Kremer, L., Zaballos, A., and Márquez, G. (1998). Identification of CCR8 as the specific receptor for the human beta-chemokine I-309: cloning and molecular characterization of murine CCR8 as the receptor for TCA-3. J. Immunol. 160, 1975-1981. Goya, I., Villares, R., Zaballos, A., Gutiérrez, J., Kremer, L., Gonzalo, J. A., Varona, R., Carramolino, L., Serrano, A., Pallarés, P., Criado, L. M., Kolbeck, R., Torres, M., Coyle, A. J., Gutiérrez-Ramos, J. C., MartínezA, C., and Márquez, G. (2003). Absence of CCR8 does not impair the response to ovalbumin-induced allergic airway disease. J. Immunol. 170, 2138-2146.

Gros, E., Bussmann, C., Bieber, T., Förster, I., and Novak, N. (2009). Expression of chemokines and chemokine receptors in lesional and nonlesional upper skin of patients with atopic dermatitis. J. Allergy Clin. Immunol. 124, 753-760 el.

Guilliams, M., and Crozat, K., Henri, S., Tamoutounour, S., Grenot, P., Devilard, E., de Bovis, B., Alexopoulou, L., Dalod, M., and Malissen, B. (2010). Skin-draining lymph nodes contain dermis-derived CD103(-) dendritic cells that constitutively produce retinoic acid and induce Foxp3(+) regulatory T cells. Blood 115, 1958-1968.

Guttman-Yassky, E., Lowes, M. A., Fuentes-Duculan, J., Whynot, J., Novitskaya, I., Cardinale, I., Haider, A., Khatcherian, A., Carucci, J. A.,
Bergman, R., and Krueger, J. G. (2007). Major differences in inflammatory dendritic cells and their products distinguish atopic dermatitis from Psoriasis. J. Allergy Clin. Immunol. 119, 1210-1217.

Hammerschmidt, S.I., Ahrendt, M., Bode, U., Wahl, B., Kremmer, E., Förster, R., and Pabst, O. (2008). Stromal mesenteric lymph node cells are essential for the generation of gut-homing $\mathrm{T}$ cells in vivo. J. Exp. Med. 205, 2483-2490.

Haque, N.S., Zhang, X., French, D. L., Li, J., Poon, M., Fallon, J. T., Gabel, B. R., Taubman, M. B., Koschinsky, M., and Harpel, P. C. (2000). CC chemokine I-309 is the principal monocyte chemoattractant induced by apolipoprotein (a) in human vascular endothelial cells. Circulation 102, 786-792.

Harasawa, H., Yamada, Y., Hieshima, K., Jin, Z., Nakayama, T., Yoshie, O., Shimizu, K., Hasegawa, H., Hayashi, T., Imaizumi, Y., Ikeda, S., Soda, H., Soda, H., Atogami, S., Takasaki, Y., Tsukasaki, K., Tomonaga, M., Murata, K., Sugahara, K., Tsuruda, K., and Kamihira, S. (2006). Survey of chemokine receptor expression reveals frequent co-expression of skin-homing CCR4 and CCR10 in adult T-cell leukemia/lymphoma. Leuk. Lymphoma 47, 2163-2173.

Harper, E. G., Guo, C., Rizzo, H., Lillis, J. V., Kurtz, S. E., Skorcheva, I., Purdy, D., Fitch, E., Iordanov, M., and Blauvelt, A. (2009). Th17 cytokines stimulate CCL20 expression in keratinocytes in vitro and in vivo: implications for Psoriasis pathogenesis. $J$. Invest. Dermatol. 129, 2175-2183.

Hasegawa, M., Sato, S., Echigo, T., Hamaguchi, Y., Yasui, M., and Takehara, K. (2005). Up regulated expression of fractalkine/CX3CL1 and CX3CR1 in patients with systemic sclerosis. Ann. Rheum. Dis. 64, 21-28.

Hayakawa, I., Hasegawa, M., Matsushita, T., Yanaba, K., Kodera, M., Komura, K., Takehara, K., and Sato, S. (2005). Increased cutaneous Tcell-attracting chemokine levels in sera from patients with systemic sclerosis. Rheumatology (Oxford) 44, 873-878.

Heydtmann, M., Lalor, P. F., Eksteen, J. A., Hübscher, S. G., Briskin, M., and Adams, D. H. (2005). CXC chemokine ligand 16 promotes integrin-mediated adhesion of liverinfiltrating lymphocytes to cholangiocytes and hepatocytes within the inflamed human liver. J. Immunol. 174, 1055-1062. 
Hijnen, D., De Bruin-Weller, M., Oosting, B., Lebre, C., De Jong, E., Bruijnzeel-Koomen, C., and Knol, E. (2004). Serum thymus and activation-regulated chemokine (TARC) and cutaneous $\mathrm{T}$ cellattracting chemokine (CTACK) levels in allergic diseases: TARC and CTACK are disease-specific markers for atopic dermatitis. J. Allergy Clin. Immunol. 113, 334-340.

Hintzen, C. (2008). Oncostatin Minduced and constitutive activation of the JAK2/STAT5/CIS pathway suppresses CCL1, but not CCL7 and CCL8, chemokine expression. J. Immunol. 181, 7341-7349.

Hirakawa, S., Detmar, M., Kerjaschki, D., Nagamatsu, S., Matsuo, K., Tanemura, A., Kamata, N., Higashikawa, K., Okazaki, H., Kameda, K., Nishida-Fukuda, H., Mori, H., Hanakawa, Y., Sayama, K., Shirakata, Y., Tohyama, M., Tokumaru, S., Katayama, I., and Hashimoto, K. (2009). Nodal lymphangiogenesis and metastasis: role of tumorinduced lymphatic vessel activation in extramammary Paget's disease. Am. J. Pathol. 175, 2235-2248.

Holland, D. B., Bojar, R. A., Farrar, M. D., and Holl, K. T. (2009). Differential innate immune responses of a living skin equivalent model colonized by Staphylococcus epidermidis or Staphylococcus aureus. FEMS Microbiol. Lett. 290, 149-155.

Homey, B., Alenius, H., Müller, A., Soto, H., Bowman, E. P., Yuan, W., McEvoy, L., Lauerma, A. I., Assmann, T., Bünemann, E., Lehto, M., Wolff, H., Yen, D., Marxhausen, H., To, W., Sedgwick, J., Ruzicka, T., Lehmann, P., and Zlotnik, A. (2002). CCL27CCR10 interactions regulate $\mathrm{T}$ cellmediated skin inflammation. Nat. Med. 8, 157-165.

Homey, B., Meller, S., Savinko, T., Alenius, H., and Lauerma, A. (2007). Modulation of chemokines by staphylococcal superantigen in atopic dermatitis. Chem. Immunol. Allergy 93, 181-194.

Homey, B., Wang, W., Soto, H., Buchanan, M. E., Wiesenborn, A., Catron, D., Müller, A., McClanahan, T. K., Dieu-Nosjean, M. C., Orozco, R., Ruzicka, T., Lehmann, P., Oldham, E., and Zlotnik, A. (2000). Cutting edge: the orphan chemokine receptor $G$ protein-coupled receptor-2 (GPR-2, CCR10) binds the skinassociated chemokine CCL27 (CTACK/ALP/ILC). J. Immunol. 164, 3465-3470.

Horikawa, T., Nakayama, T., Hikita, I., Yamada, H., Fujisawa, R., Bito,
T., Harada, S., Fukunaga, A., Chantry, D., Gray, P. W., Morita, A., Suzuki, R., Tezuka, T., Ichihashi, M., and Yoshie, O. (2002). IFNgamma-inducible expression of thymus and activationregulated chemokine/CCL17 and macrophage-derived chemokine/CCL22 in epidermal keratinocytes and their roles in atopic dermatitis. Int. Immunol. 14, 767-773.

Hudak, S., Hagen, M., Liu, Y., Catron, D., Oldham, E., McEvoy, L. M., and Bowman, E. P. (2002). Immune surveillance and effector functions of CCR10(+) skin homing T cells. J. Immunol. 169, 1189-1196.

Humphreys, T. L., Baldridge, L. A., Billings, S. D., Campbell, J. J., and Spinola, S. M. (2005). Trafficking pathways and characterization of CD4 and CD8 cells recruited to the skin of humans experimentally infected with Haemophilus ducreyi. Infect. Immun. 73, 3896-3902.

Iellem, A., Mariani, M., Lang, R., Recalde, H., Panina-Bordignon, P., Sinigaglia, F., and D'Ambrosio, D. (2001). Unique chemotactic response profile and specific expression of chemokine receptors CCR4 and CCR 8 by CD4(+)CD25(+) regulatory T cells. J. Exp. Med. 194, 847-853.

Iliev, I. D., Mileti, E., Matteoli, G., Sonzogni, A., Sampietro, G. M., Foschi, D., Caprioli, F., Viale, G., and Rescigno, M. (2009). Human intestinal epithelial cells promote the differentiation of tolerogenic dendritic cells. Gut 58, 1481-1489.

Inngjerdingen, M., Damaj, B., and Maghazachi, A. A. (2000). Human NK cells express CC chemokine receptors 4 and 8 and respond to thymus and activation-regulated chemokine, macrophage-derived chemokine, and I-309. J. Immunol. 164, 4048-4054

Inngjerdingen, M., Damaj, B., and Maghazachi, A. A. (2001). Expression and regulation of chemokine receptors in human natural killer cells. Blood 97, 367-375.

Ishida, T., Inagaki, H., Kusumoto, S., Inagaki, A., Komatsu, H., Iida, S., Harada, S., Takeuchi, G., and Uedaa, R. (2005). CC chemokine receptor 4-positive diffuse large B-cell lymphoma involving the skin: a case report. Int. J. Hematol. 82, 148-151.

Islam, S. A., Chang, D. S., Colvin, R. A., Byrne, M. H., McCully, M. L., Moser, B., Lira, S. A., Charo, I. F., and Luster, A. D. (2011). Mouse CCL8, a CCR8 agonist, promotes atopic dermatitis by recruiting IL-5+
$\mathrm{T}(\mathrm{H}) 2$ cells. Nat. Immunol. 12, 167-177.

Iwata, M., and Hirakiyama, A., Eshima, Y., Kagechika, H., Kato, C., and Song, S. Y. (2004). Retinoic acid imprints gut-homing specificity on $\mathrm{T}$ cells. Immunity 21, 527-538.

Izraely, S., Klein, A., Sagi-Assif, O., Meshel, T., Tsarfaty, G., Hoon, D. S., and Witz, I. P. (2010). Chemokine-chemokine receptor axes in melanoma brain metastasis. Immunol. Lett. 130, 107-114.

Jaensson, E., and Uronen-Hansson, H., Pabst, O., Eksteen, B., Tian, J., Coombes, J. L., Berg, P. L., Davidsson, T., Powrie, F., JohanssonLindbom, B., and Agace, W. W. (2008). Small intestinal CD103 dendritic cells display unique functional properties that are conserved between mice and humans. J. Exp. Med. 205, 2139-2149.

Jaensson-Gyllenback, E., Kotarsky, K., Zapata, F., Persson, E. K., Gundersen, T. E., Blomhoff, R., and Agace, W. W. (2011). Bile retinoids imprint intestinal CD103(+) dendritic cells with the ability to generate gut-tropic T cells. Mucosal Immunol. 4, 438-447.

Johansson-Lindbom, B., Svensson, M. Pabst, O., Palmqvist, C., Marquez, G., Förster, R., and Agace, W. W. (2005). Functional specialization of gut CD103 dendritic cells in the regulation of tissue-selective T cell homing. J. Exp. Med. 202, 1063-1073.

Kai, H., Kadono, T., Kakinuma, T., Tomita, M., Ohmatsu, H., Asano, Y., Tada, Y., Sugaya, M., and Sato, S. (2011). CCR10 and CCL27 are overexpressed in cutaneous squamous cell carcinoma. Pathol. Res. Pract. 207, 43-48.

Kakinuma, T., Saeki, H., Tsunemi, Y., Fujita, H., Asano, N., Mitsui, H. Tada, Y., Wakugawa, M., Watanabe, T., Torii, H., Komine, M., Asahina, A., Nakamura, K., and Tamaki, K. (2003a). Increased serum cutaneous $\mathrm{T}$ cell-attracting chemokine (CCL27) levels in patients with atopic dermatitis and Psoriasis vulgaris. J. Allergy Clin. Immunol. 111, 592-597.

Kakinuma, T., Wakugawa, M., Nakamura, K., Hino, H., Matsushima, K., and Tamaki, K. (2003b). High level of thymus and activation-regulated chemokine in blister fluid and sera of patients with bullous pemphigoid. Br. J. Dermatol. 148, 203-210.

Kamsteeg, M., Jansen, P. A., van Vlijmen-Willems, I. M., van Erp, P. E., Rodijk-Olthuis, D., van der Valk, P. G., Feuth, T., Zeeuwen, P. L., and Schalkwijk, J. (2010). Molecular diagnostics of Psoriasis, atopic dermatitis, allergic contact dermatitis and irritant contact dermatitis. $\mathrm{Br}$. J. Dermatol. 162, 568-578.

Kanda, N., Koike, S., and Watanabe, S. (2005). IL-17 suppresses TNFalpha-induced CCL27 production through induction of COX-2 in human keratinocytes. J. Allergy Clin. Immunol. 116, 1144-1150.

Kanda, N., Mitsui, H., and Watanabe, S. (2004). Prostaglandin E(2) suppresses CCL27 production through EP2 and EP3 receptors in human keratinocytes. J. Allergy Clin. Immunol. 114, 1403-1409.

Kang, S.G., Park, J., Cho, J. Y., Ulrich, B., and Kim, C. H. (2011). Complementary roles of retinoic acid and TGF-betal in coordinated expression of mucosal integrins by T cells. Mucosal Immunol. 4, 66-82.

Keller, M., Spanou, Z., Schaerli, P., Britschgi, M., Yawalkar, N., Seitz, M., Villiger, P. M., and Pichler, W. J. (2005). T cell-regulated neutrophilic inflammation in autoinflammatory diseases. J. Immunol. 175, 7678-7686.

Kim, B. E., Leung, D. Y., Streib, J. E., Kisich, K., Boguniewicz, M., Hamid, Q. A., and Howell, M. D. (2007) Macrophage inflammatory protein 3alpha deficiency in atopic dermatitis skin and role in innate immune response to vaccinia virus. J. Allergy Clin. Immunol. 119, 457-463.

Kremer, L., Carramolino, L., Goya, I., Zaballos, A., Gutiérrez, J., MorenoOrtiz, M., del, C., Martínez-A, C., and Márquez, G. (2001). The transient expression of C-C chemokine receptor 8 in thymus identifies a thymocyte subset committed to become CD4+ single-positive T cells. J. Immunol. 166, 218-225.

Kriehuber, E., Breiteneder-Geleff, S., Groeger, M., Soleiman, A., Schoppmann, S. F., Stingl, G., Kerjaschki, D., and Maurer, D. (2001). Isolation and characterization of dermal lymphatic and blood endothelial cells reveal stable and functionally specialized cell lineages. J. Exp. Med. 194, 797-808.

Kurth, I., Willimann, K., Schaerli, P., Hunziker, T., Clark-Lewis, I., and Moser, B. (2001). Monocyte selectivity and tissue localization suggests a role for breast and kidney-expressed chemokine (BRAK) in macrophage development. J. Exp. Med. 194, 855-861.

Lehtimaki, S., Tillander, S., Puustinen, A., Matikainen, S., Nyman, T., Fyhrquist, N., Savinko, T., Majuri, M. L., Wolff, H., Alenius, H., and Lauerma, A. (2010). Absence of 
CCR4 exacerbates skin inflammation in an oxazolone-induced contact hypersensitivity model. J. Invest. Dermatol. 130, 2743-2751.

Leipe, J., Grunke, M., Dechant, C., Reindl, C., Kerzendorf, U., SchulzeKoops, H., and Skapenko, A. (2010). Role of Th17 cells in human autoimmune arthritis. Arthritis Rheum. 62, 2876-2885.

Liu, L., Fuhlbrigge, R. C., Karibian, K., Tian, T., and Kupper, T. S. (2006). Dynamic programming of CD8 $\mathrm{T}$ cell trafficking after live viral immunization. Immunity 25, 511-520.

Loetscher, P., Seitz, M., Clark-Lewis, I., Baggiolini, M., and Moser, B. (1996). Activation of NK cells by $\mathrm{CC}$ chemokines. Chemotaxis, $\mathrm{Ca} 2+$ mobilization, and enzyme release. $J$. Immunol. 156, 322-327.

Louahed, J., Struyf, S., Demoulin, J. B., Parmentier, M., Van Snick, J., Van Damme, J., Renauld, J. C. (2003). CCR8-dependent activation of the RAS/MAPK pathway mediates antiapoptotic activity of I-309/CCL1 and vMIP-I. Eur. J. Immunol. 33, 494-501.

Lucas, A. D., Chadwick, N., Warren, B. F., Jewell, D. P., Gordon, S., Powrie, F., and Greaves, D. R. (2001). The transmembrane form of the CX3CL1 chemokine fractalkine is expressed predominantly by epithelial cells in vivo. Am. J. Pathol. 158, 855-866.

Luttichau, H.R., Stine, J., Boesen, T. P., Johnsen, A. H., Chantry, D., Gerstoft, J., and Schwartz, T. W. (2000). A highly selective CC chemokine receptor (CCR) 8 antagonist encoded by the poxvirus molluscum contagiosum. J. Exp. Med. 191, 171-180.

Martin, A., Gallino, N., Gagliardi, J., Ortiz, S., Lascano, A. R., Diller, A., Daraio, M. C., Kahn, A., Mariani, A. L., and Serra, H. M. (2002). Early inflammatory markers in elicitation of allergic contact dermatitis. BMC Dermatol. 2, 9. doi: 10.1186/14715945-2-9

Meller, S., Lauerma, A. I., Kopp, F. M., Winterberg, F., Anthoni, M., Müller, A., Gombert, M., Haahtela, A., Alenius, H., Rieker, J., Dieu-Nosjean, M. C., Kubitza, R. C., Gleichmann, E., Ruzicka, T., Zlotnik, A., and Homey, B. (2007). Chemokine responses distinguish chemical-induced allergic from irritant skin inflammation: memory $\mathrm{T}$ cells make the difference. J. Allergy Clin. Immunol. 119, 1470-1480.

Meller, S., Winterberg, F., Gilliet, M., Müller, A., Lauceviciute, I.,
Rieker, J., Neumann, N. J., Kubitza, R., Gombert, M., Bünemann, E., Wiesner, U., Franken-Kunkel, P., Kanzler, H., Dieu-Nosjean, M. C., Amara, A., Ruzicka, T., Lehmann, P., Zlotnik, A., and Homey, B. (2005). Ultraviolet radiation-induced injury, chemokines, and leukocyte recruitment: an amplification cycle triggering cutaneous lupus erythematosus. Arthritis Rheum. 52, 1504-1516.

Meuter, S., and Moser, B. (2008). Constitutive expression of CXCL14 in healthy human and murine epithelial tissues. Cytokine 44, 248-255.

Meuter, S., Schaerli, P., Roos, R. S., Brandau, O., Bösl, M. R., von Andrian, U. H., and Moser, B. (2007). Murine CXCL14 is dispensable for dendritic cell function and localization within peripheral tissues. Mol. Cell. Biol. 27, 983-992.

Mikhak, Z., Fukui, M., Farsidjani, A., Medoff, B. D., Tager, A. M., and Luster, A. D. (2009). Contribution of CCR4 and CCR8 to antigen-specific $\mathrm{T}(\mathrm{H}) 2$ cell trafficking in allergic pulmonary inflammation. J. Allergy Clin. Immunol. 123, 67-73 e3.

Miller, M. D., and Krangel, M. S. (1992). The human cytokine I309 is a monocyte chemoattractant. Proc. Natl. Acad. Sci. U.S.A. 89, 2950-2954.

Miller, M. D., Hata, S., De Waal Malefyt, R., and Krangel, M. S. (1989). A novel polypeptide secreted by activated human T lymphocytes. J. Immunol. 143, 2907-2916.

Molenaar, R., and Greuter, M., van der Marel, A. P., Roozendaal, R., Martin, S. F., Edele, F., Huehn, J., Förster, R., O’Toole, T., Jansen, W., Eestermans, I. L., Kraal, G., and Mebius, R. E. (2009). Lymph node stromal cells support dendritic cell-induced guthoming of T cells. J. immunol. 183, 6395-6402.

Montes-Vizuet, R., Vega-Miranda, A., Valencia-Maqueda, E., NegreteGarcía, M. C., Velásquez, J. R., and Teran, L. M. (2006). CC chemokine ligand 1 is released into the airways of atopic asthmatics. Eur. Res. J. 28, 59-67.

Mora, J. R., and Iwata, M., and von Andrian, U. H. (2008). Vitamin effects on the immune system: vitamins A and D take centre stage. Nat. Rev. Immunol. 8, 685-698.

Mora, J. R., Cheng, G., Picarella, D., Briskin, M., Buchanan, N., and von Andrian, U. H. (2005). Reciprocal and dynamic control of CD8 T cell homing by dendritic cells from skinand gut-associated lymphoid tissues. J. Exp. Med. 201, 303-316.
Morales, J., Homey, B., Vicari, A. P., Hudak, S., Oldham, E., Hedrick, J. Orozco, R., Copel, N. G., Jenkins, N. A., McEvoy, L. M., and Zlotnik, A. (1999). CTACK, a skinassociated chemokine that preferentially attracts skin-homing memory T cells. Proc. Natl. Acad. Sci. U.S.A. 96, 14470-14475.

Morgan, A. J., Guillen, C., Symon, F. A., Huynh, T. T., Berry, M. A., Entwisle, J. J., Briskin, M., Pavord, I. D., and Wardlaw, A. J. (2005). Expression of CXCR6 and its ligand CXCL16 in the lung in health and disease. Clin. Exp. Allergy 35, 1572-1580.

Morteau, O., Gerard, C., Lu, B., Ghiran, S., Rits, M., Fujiwara, Y., Law, Y., Distelhorst, K., Nielsen, E. M., Hill, E. D., Kwan, R., Lazarus, N. H., Butcher, E. C., and Wilson, E. (2008). An indispensable role for the chemokine receptor CCR10 in IgA antibody-secreting cell accumulation. J. Immunol. 181, 6309-6315.

Mullegger, R. R., Means, T. K., Shin, J. J., Lee, M., Jones, K. L., Glickstein, L. J., Luster, A. D., and Steere, A. C. (2007). Chemokine signatures in the skin disorders of Lyme borreliosis in Europe: predominance of CXCL9 and CXCL10 in erythema migrans and acrodermatitis and CXCL13 in lymphocytoma. Infect. Immun. 75, 4621-4628.

Mutalithas, K., Guillen, C., Raport, C., Kolbeck, R., Soler, D., Brightling, C. E., Pavord, I. D., and Wardlaw, A. J. (2010). Expression of CCR8 is increased in asthma. Clin. Exp. Allergy 40, 1175-1185.

Nakajima, T., Inagaki, N., Tanaka, H., Tanaka, A., Yoshikawa, M., Tamari, M., Hasegawa, K., Matsumoto, K., Tachimoto, H., Ebisawa, M., Tsujimoto, G., Matsuda, H., Nagai, H., and Saito, H. (2002). Marked increase in CC chemokine gene expression in both human and mouse mast cell transcriptomes following Fcepsilon receptor I crosslinking: an interspecies comparison. Blood 100, 3861-3868.

Nakayama, T., Fujisawa, R., Yamada, H., Horikawa, T., Kawasaki, H., Hieshima, K., Izawa, D., Fujiie, S., Tezuka, T., and Yoshie, O. (2001). Inducible expression of a CC chemokine liver- and activation-regulated chemokine (LARC)/macrophage inflammatory protein (MIP)-3 alpha/CCL20 by epidermal keratinocytes and its role in atopic dermatitis. Int. Immunol. 13, 95-103.

Nakayama, T., Watanabe, Y., Oiso, N., Higuchi, T., Shigeta, A., Mizuguchi,
N., Katou, F., Hashimoto, K., Kawada, A., and Yoshie, O. (2010). Eotaxin-3/CC chemokine ligand 26 is a functional ligand for CX3CR1. J. Immunol. 185, 6472-6479.

Napolitano, M., Zingoni, A., Bernardini, G., Spinetti, G., Nista, A., Storlazzi, C. T., Rocchi, M., and Santoni, A. (1996). Molecular cloning of TER1, a chemokine receptor-like gene expressed by lymphoid tissues. J. Immunol. 157, 2759-2763.

Narducci, M.G., Scala, E., Bresin, A., Caprini, E., Picchio, M. C., Remotti, D., Ragone, G., Nasorri, F., Frontani, M., Arcelli, D., Volinia, S., Lombardo, G. A., Baliva, G., Napolitano, M., and Russo, G. (2006). Skin homing of Sezary cells involves SDF-1-CXCR4 signaling and down-regulation of CD26/dipeptidylpeptidase IV. Blood 107, 1108-1115.

Niederreither, K., and Dolle, P. (2008). Retinoic acid in development: towards an integrated view. Nat. Rev. Genet. 9, 541-553.

Niyonsaba, F., Ushio, H., Nakano, N., Ng, W., Sayama, K., Hashimoto, K., Nagaoka, I., Okumura, K., and Ogawa, H. (2007). Antimicrobial peptides human beta-defensins stimulate epidermal keratinocyte migration, proliferation and production of proinflammatory cytokines and chemokines. J. Invest. Dermatol. 127, 594-604.

Nouri-Aria, K. T., Wilson, D., Francis, J. N., Jopling, L. A., Jacobson, M. R., Hodge, M. R., Andrew, D. P., Till, S. J., Varga, E. M., Williams, T. J., Pease, J. E., Lloyd, C. M., Sabroe, I., and Durham, S. R. (2002). CCR4 in human allergen-induced late responses in the skin and lung. Eur. J. Immunol. 32, 1933-1938.

Oh, S.T., Schramme, A., Tilgen, W., Gutwein, P., and Reichrath, J. (2009). Overexpression of CXCL16 in lesional psoriatic skin. Dermatoendocrinol. 1, 114-118.

Olaru, F., and Jensen, L. E. (2010). Chemokine expression by human keratinocyte cell lines after activation of Toll-like receptors. Exp. Dermatol. 19, e314-316.

Oo, Y. H., Weston, C. J., Lalor, P. F., Curbishley, S. M., Withers, D. R., Reynolds, G. M., Shetty, S., Harki, J., Shaw, J. C., Eksteen, B., Hubscher, S. G., Walker, L. S., and Adams, D. H. (2010). Distinct roles for CCR4 and CXCR3 in the recruitment and positioning of regulatory $\mathrm{T}$ cells in the inflamed human liver. J. Immunol. 184, 2886-2898. 
Ottaviani, C., Nasorri, F., Bedini, C., de Pità, O., Girolomoni, G., Cavani A. (2006). CD56brightCD16(-) NK cells accumulate in psoriatic skin in response to CXCL10 and CCL5 and exacerbate skin inflammation. Eur. J. Immunol. 36, 118-128.

Pablos, J. L., Mara, A., Bouloc, A., Santiago, B., Caruz, A., Galindo, M., Delaunay, T., Virelizier, J. L., and Arenzana-Seisdedos, F. (1999). Stromal-cell derived factor is expressed by dendritic cells and endothelium in human skin. Am. J. Pathol. 155, 1577-1586.

Pan, J., Kunkel, E. J., Gosslar, U., Lazarus, N., Langdon, P., Broadwell, K., Vierra, M. A., Genovese, M. C., Butcher, E. C., and Soler, D. (2000). A novel chemokine ligand for CCR10 and CCR3 expressed by epithelial cells in mucosal tissues. J. Immunol. 165, 2943-2949.

Panina-Bordignon, P., Papi, A., Mariani, M., Di Lucia, P., Casoni, G., Bellettato, C., Buonsanti, C., Miotto, D., Mapp, C., Villa, A., Arrigoni, G., Fabbri, L. M., and Sinigaglia, F. (2001). The C-C chemokine receptors CCR4 and CCR8 identify airway $\mathrm{T}$ cells of allergen-challenged atopic asthmatics. J. Clin. Invest. 107, 1357-1364.

Papadopoulos, E. J., Sassetti, C., Saeki, H., Yamada, N., Kawamura, T., Fitzhugh, D. J., Saraf, M. A., Schall, T., Blauvelt, A., Rosen, S. D., and Hwang, S. T. (1999). Fractalkine, a CX3C chemokine, is expressed by dendritic cells and is up-regulated upon dendritic cell maturation. Eur. J. Immunol. 29, 2551-2559.

Pivarcsi, A., Müller, A., Hippe, A., Rieker, J., van Lierop, A., Steinhoff, M., Seeliger, S., Kubitza, R., Pippirs, U., Meller, S., Gerber, P. A., Liersch, R., Buenemann, E., Sonkoly, E., Wiesner, U., Hoffmann, T. K., Schneider, L., Piekorz, R., Enderlein, E., Reifenberger, J., Rohr, U. P., Haas, R., Boukamp, P., Haase, I., Nürnberg, B., Ruzicka, T., Zlotnik, A., and Homey, B. (2007). Tumor immune escape by the loss of homeostatic chemokine expression. Proc. Natl. Acad. Sci. U.S.A. 104, 19055-19060.

Qu, C., Edwards, E. W., Tacke, F., Angeli, V., Llodrá, J., Sanchez-Schmitz, G., Garin, A., Haque, N. S., Peters, W., van Rooijen, N., Sanchez-Torres, C., Bromberg, J., Charo, I. F., Jung, S., Lira, S. A., and Randolph, G. J. (2004). Role of CCR8 and other chemokine pathways in the migration of monocyte-derived dendritic cells to lymph nodes. J. Exp. Med. 200, 1231-1241.
Raychaudhuri, S. P., Jiang, W. Y., and Farber, E. M. (2001). Cellular localization of fractalkine at sites of inflammation: antigen-presenting cells in Psoriasis express high levels of fractalkine. Br. J. Dermatol. 144, 1105-1113.

Reichrath, J. (2007). Vitamin D and the skin: an ancient friend, revisited. Exp. Dermatol. 16, 618-625.

Reinhardt, R. L., Khoruts, A., Merica, R., Zell, T., Jenkins, M. K. (2001). Visualizing the generation of memory CD4 T cells in the whole body. Nature 410, 101-105.

Reiss, Y., and Proudfoot, A. E., Power, C. A., Campbell, J. J., Butcher, E. C. (2001). CC chemokine receptor (CCR) 4 and the CCR10 ligand cutaneous $\mathrm{T}$ cell-attracting chemokine (CTACK) in lymphocyte trafficking to inflamed skin. J. Exp. Med. 194, 1541-1547.

Rimoldi, M., Chieppa, M., Salucci, V., Avogadri, F., Sonzogni, A., Sampietro, G. M., Nespoli, A., Viale, G., Allavena, P., and Rescigno, M. (2005). Intestinal immune homeostasis is regulated by the crosstalk between epithelial cells and dendritic cells. Nat. Immunol. 6, 507-514.

Roos, R.S., Loetscher, M., Legler, D. F., Clark-Lewis, I., Baggiolini, M., and Moser, B. (1997). Identification of CCR8, the receptor for the human CC chemokine I-309. J. Biol. Chem. 272, 17251-17254.

Roos, T. C., Jugert, F. K., Merk, H. F., and Bickers, D. R. (1998). Retinoid metabolism in the skin. Pharmacol. Rev. 50, 315-333.

Rottman, J. B., Smith, T. L., Ganley, K. G., Kikuchi, T., and Krueger, J. G. (2001). Potential role of the chemokine receptors CXCR3, CCR4, and the integrin alphaEbeta7 in the pathogenesis of Psoriasis vulgaris. Lab. Invest. 81, 335-347.

Sallusto, F., Kremmer, E., Palermo, B., Hoy, A., Ponath, P., Qin, S., Förster, R., Lipp, M., and Lanzavecchia, A. (1999). Switch in chemokine receptor expression upon TCR stimulation reveals novel homing potential for recently activated T cells. Eur. J. Immunol. 29, 2037-2045.

Samson, M., Stordeur, P., Labbé, O., Soularue, P., Vassart, G., and Parmentier, M. (1996). Molecular cloning and chromosomal mapping of a novel human gene, ChemR1, expressed in T lymphocytes and polymorphonuclear cells and encoding a putative chemokine receptor. Eur. J. Immunol. 26, 3021-3028.
Schaerli, P., Ebert, L., Willimann, K., Blaser, A., Roos, R. S., Loetscher, P., and Moser, B. (2004). A skinselective homing mechanism for human immune surveillance T cells. J. Exp. Med. 199, 1265-1275.

Schaerli, P., Willimann, K., Ebert, L. M., Walz, A., and Moser, B. (2005). Cutaneous CXCL14 targets blood precursors to epidermal niches for Langerhans cell differentiation. Immunity 23, 331-342.

Schmuth, M., Neyer, S., Rainer, C., Grassegger, A., Fritsch, P., Romani, N., and Heufler, C. (2002). Expression of the C-C chemokine MIP3 alpha/CCL20 in human epidermis with impaired permeability barrier function. Exp. Dermatol. 11, 135-142.

Scholz, F., Schulte, A., Adamski, F., Hundhausen, C., Mittag, J., Schwarz, A., Kruse, M. L., Proksch, E., and Ludwig, A. (2007). Constitutive expression and regulated release of the transmembrane chemokine CXCL16 in human and murine skin. J. Invest. Dermatol. 127, 1444-1455.

Sebastiani, S., Albanesi, C., Nasorri, F., Girolomoni, G., and Cavani, A. (2002). Nickel-specific CD4(+) and CD8(+) $\mathrm{T}$ cells display distinct migratory responses to chemokines produced during allergic contact dermatitis. J. Invest. Dermatol. 118, 1052-1058.

Sebastiani, S., Allavena, P., Albanesi, C., Nasorri, F., Bianchi, G., Traidl, C., Sozzani, S., Girolomoni, G., and Cavani, A. (2001). Chemokine receptor expression and function in CD4+ T lymphocytes with regulatory activity. J. Immunol. 166, 996-1002.

Sells, R. E., and Hwang, S. T. (2010). Paradoxical increase in skin inflammation in the absence of CCR4. J. Invest. Dermatol. 130, 2697-2699.

Selvan, R. S., Butterfield, J. H., and Krangel, M. S. (1994). Expression of multiple chemokine genes by a human mast cell leukemia. J. Biol. Chem. 269, 13893-13898.

Selvan, R.S., Zhou, L. J., and Krangel, M. S. (1997). Regulation of I-309 gene expression in human monocytes by endogenous interleukin-1. Eur. J. Immunol. 27, 687-694.

Shellenberger, T. D., Wang, M., Gujrati, M., Jayakumar, A., Strieter, R. M., Burdick, M. D., Ioannides, C. G., Efferson, C. L., El-Naggar, A. K., Roberts, D., Clayman, G. L., and Frederick, M. J. (2004). BRAK/CXCL14 is a potent inhibitor of angiogenesis and a chemotactic factor for immature dendritic cells. Cancer Res. 64, 8262-8270.
Shurin, G.V., Ferris, R. L., Tourkova, I. L., Perez, L., Lokshin, A., Balkir, L., Collins, B., Chatta, G. S., and Shurin, M. R. (2005). Loss of new chemokine CXCL14 in tumor tissue is associated with low infiltration by dendritic cells (DC), while restoration of human CXCL14 expression in tumor cells causes attraction of DC both in vitro and in vivo. $J$. Immunol. 174, 5490-5498.

Sigmundsdottir, H., and Butcher, E. C. (2008). Environmental cues, dendritic cells and the programming of tissue-selective lymphocyte trafficking. Nat. Immunol. 9, 981-987.

Sigmundsdottir, H., Pan, J., Debes, G. F., Alt, C., Habtezion, A., Soler, D., and Butcher, E. C. (2007). DCs metabolize sunlight-induced vitamin D3 to "program" $\mathrm{T}$ cell attraction to the epidermal chemokine CCL27. Nat. Immunol. 8, 285-293.

Sokolov, V.O., Krasnikova, T. L., Prokofieva, L. V., Kukhtina, N. B., and Arefieva, T. I. (2009). Expression of markers of regulatory CD4 CD25 foxp3 cells in atherosclerotic plaques of human coronary arteries. Bull. Exp. Biol. Med. 147, 726-729.

Soler, D., Chapman, T. R., Poisson, L. R., Wang, L., Cote-Sierra, J., Ryan, M., McDonald, A., Badola, S., Fedyk, E., Coyle, A. J., Hodge, M. R., and Kolbeck, R. (2006). CCR8 expression identifies CD4 memory T cells enriched for FOXP3+ regulatory and Th2 effector lymphocytes. J. Immunol. 177, 6940-6951.

Sozzani, S., Luini, W., Bianchi, G., Allavena, P., Wells, T. N., Napolitano, M., Bernardini, G., Vecchi, A., D’Ambrosio, D., Mazzeo, D., Sinigaglia, F., Santoni, A., Maggi, E., Romagnani, S., and Mantovani, A. (1998). The viral chemokine macrophage inflammatory proteinII is a selective Th2 chemoattractant. Blood 92, 4036-4039.

Spiekstra, S. W., Toebak, M. J., SampatSardjoepersad, S., van Beek, P. J., Boorsma, D. M., Stoof, T. J., von Blomberg, B. M., Scheper, R. J., Bruynzeel, D. P., Rustemeyer, T. and Gibbs, S. (2005). Induction of cytokine (interleukin-1alpha and tumor necrosis factor-alpha) and chemokine (CCL20, CCL27, and CXCL8) alarm signals after allergen and irritant exposure. Exp. Dermatol. 14, 109-116.

Spinetti, G., Bernardini, G., Camarda, G., Mangoni, A., Santoni, A., Capogrossi, M. C., and Napolitano, M. (2003). The chemokine receptor CCR8 mediates rescue from dexamethasone-induced apoptosis via an ERK-dependent pathway. $J$. Leukoc. Biol. 73, 201-207. 
Starnes, T., Rasila, K. K., Robertson, M. J., Brahmi, Z., Dahl, R., Christopherson, K., and Hromas, R. (2006). The chemokine CXCL14 (BRAK) stimulates activated NK cell migration: implications for the downregulation of CXCL14 in malignancy. Exp. Hematol. 34, 1101-1105.

Sugaya, M., Nakamura, K., Mitsui, H., Takekoshi, T., Saeki, H., and Tamaki, K. (2003). Human keratinocytes express fractalkine/CX3CL1. J. Dermatol. Sci. 31, 179-187.

Sumiyoshi, K., Nakao, A., Setoguchi, Y., Tsuboi, R., Okumura, K., and Ogawa, H. (2003). TGF-beta/Smad signaling inhibits IFN-gamma and TNFalpha-induced TARC (CCL17) production in HaCaT cells. J. Dermatol. Sci. 31, 53-58.

Tapia, B., Morel, E., Martín-Díaz, M. A., Díaz, R., Alves-Ferreira, J., Rubio, P., Padial, A., and Bellón, T. (2007). Up-regulation of CCL17, CCL22 and CCR4 in drug-induced maculopapular exanthema. Clin. Exp. Allergy 37, 704-713.

Tapia, B., Padial, A., Sánchez-Sabaté, E., Alvarez-Ferreira, J., Morel, E., Blanca, M., and Bellón, T. (2004). Involvement of CCL27-CCR10 interactions in drug-induced cutaneous reactions. J. Allergy Clin. Immunol. 114, 335-340.

Tiffany, H. L., Lautens, L. L., Gao, J. L., Pease, J., Locati, M., Combadiere, C., Modi, W., Bonner, T. I., and Murphy, P. M. (1997). Identification of CCR8: a human monocyte and thymus receptor for the CC chemokine I-309. J. Exp. Med. 186, 165-170.

Tohyama, M., Sayama, K., Komatsuzawa, H., Hanakawa, Y., Shirakata, Y., Dai, X., Yang, L., Tokumaru, S., Nagai, H., Hirakawa, S., Sugai, M., and Hashimoto, K. (2007). CXCL16 is a novel mediator of the innate immunity of epidermal keratinocytes. Int. Immunol. 19, 1095-1102.

Tohyama, M., Shirakara, Y., Yamasaki, K., Sayama, K., and Hashimoto, K. (2001). Differentiated keratinocytes are responsible for TNF-alpha regulated production of macrophage inflammatory protein 3alpha/CCL20, a potent chemokine for Langerhans cells. J. Dermatol. Sci. 27, 130-139.
Toksoy, A., Müller, V., Gillitzer, R., and Goebeler, M. (2007). Biphasic expression of stromal cell-derived factor-1 during human wound healing. Br. J. Dermatol. 157, 1148-1154.

Uchida, T., Suto, H., Ra, C., Ogawa, H., Kobata, T., and Okumura, K. (2002). Preferential expression of $\mathrm{T}(\mathrm{h}) 2$ type chemokine and its receptor in atopic dermatitis. Int. Immunol. 14, 1431-1438.

Van Snick, J., Houssiau, F., Proost, P., Van Damme, J., and Renauld, J. C. (1996). I-309/T cell activation gene3 chemokine protects murine $\mathrm{T}$ cell lymphomas against dexamethasoneinduced apoptosis. J. Immunol. 157, 2570-2576.

Vermi, W., Bonecchi, R., Facchetti, F., Bianchi, D., Sozzani, S., Festa, S., Berenzi, A., Cella, M., and Colonna, M. (2003). Recruitment of immature plasmacytoid dendritic cells (plasmacytoid monocytes) and myeloid dendritic cells in primary cutaneous melanomas. J. Pathol. 200, 255-268.

Vestergaard, C., Bang, K., Gesser, B., Yoneyama, H., Matsushima, K., and Larsen, C. G. (2000). A Th2 chemokine, TARC, produced by keratinocytes may recruit CLA CCR4 lymphocytes into lesional atopic dermatitis skin. J. Invest. Dermatol. 115, 640-646.

Vijayanand, P., Durkin, K., Hartmann, G., Morjaria, J., Seumois, G., Staples, K. J., Hall, D., Bessant, C., Bartholomew, M., Howarth, P. H., Friedmann, P. S., and Djukanovic, R. (2010). Chemokine receptor 4 plays a key role in $\mathrm{T}$ cell recruitment into the airways of asthmatic patients. $J$. Immunol. 184, 4568-4574.

Wakim, L. M., Waithman, J., van Rooijen, N., Heath, W. R., and Carbone, F. R. (2008). Dendritic cell-induced memory $\mathrm{T}$ cell activation in nonlymphoid tissues. Science 319, 198-202.

Wenzel, J., Henze, S., Wörenkämper, E., Basner-Tschakarjan, E., SokolowskaWojdylo, M., Steitz, J., Bieber, T., and Tüting, T. (2005). Role of the chemokine receptor CCR4 and its ligand thymus- and activationregulated chemokine/CCL17 for lymphocyte recruitment in cutaneous lupus erythematosus. J. Invest. Dermatol. 124, 1241-1248.
Wick, N., Haluza, D., Gurnhofer, E. Raab, I., Kasimir, M. T., Prinz, M., Steiner, C. W., Reinisch, C. Howorka, A., Giovanoli, P., Buchsbaum, S., Krieger, S., Tschachler, E., Petzelbauer, P., and Kerjaschki, D. (2008). Lymphatic precollectors contain a novel, specialized subpopulation of podoplanin low, CCL27expressing lymphatic endothelial cells. Am. J. Pathol. 173, 1202-1209.

Woodland, D. L., and Kohlmeier, J. E. (2009). Migration, maintenance and recall of memory $\mathrm{T}$ cells in peripheral tissues. Nat. Rev. Immunol. 9, 153-161.

Yamanaka, K., Dimitroff, C. J., Fuhlbrigge, R. C., Kakeda, M., Kurokawa, I., Mizutani, H., and Kupper, T. S. (2008). Vitamins A and $\mathrm{D}$ are potent inhibitors of cutaneous lymphocyte-associated antigen expression. J. Allergy Clin. Immunol. 121, 148-157 e3.

Yao, L., Salvucci, O., Cardones, A R., Hwang, S. T., Aoki, Y., De La Luz Sierra, M., Sajewicz, A., Pittaluga, S., Yarchoan, R., and Tosato, G. (2003). Selective expression of stromal-derived factor- 1 in the capillary vascular endothelium plays a role in Kaposi sarcoma pathogenesis. Blood 102, 3900-3905.

Ying, S., O’Connor, B., Ratoff, J., Meng, Q., Fang, C., Cousins, D., Zhang, G., Gu, S., Gao, Z., Shamji, B., Edwards, M. J., Lee, T. H., and Corrigan, C. J. (2008). Expression and cellular provenance of thymic stromal lymphopoietin and chemokines in patients with severe asthma and chronic obstructive pulmonary disease. J. Immunol. 181, 2790-2798.

Yoshie, O., Fujisawa, R., Nakayama, T., Harasawa, H., Tago, H., Izawa, D., Hieshima, K., Tatsumi, Y., Matsushima, K., Hasegawa, H., Kanamaru, A., Kamihira, S., and Yamada, Y. (2002). Frequent expression of CCR4 in adult T-cell leukemia and human T-cell leukemia virus type 1-transformed $\mathrm{T}$ cells. Blood 99, 1505-1511.

Yu, B., Koga, T., Urabe, K., Moroi, Y., Maeda, S., Yanagihara, Y., and Furue, M. (2002). Differential regulation of thymus- and activation-regulated chemokine induced by IL-4, IL13, TNF-alpha and IFN-gamma in human keratinocyte and fibroblast. J. Dermatol. Sci. 30, 29-36.

Zaballos, A., Varona, R., Gutiérrez, J., Lind, P., and Márquez, G. (1996). Molecular cloning and RNA expression of two new human chemokine receptor-like genes. Biochem. Biophys. Res. Commun. 227, 846-853.

Zhang, Y., Luxon, B. A., Casola, A., Garofalo, R. P., Jamaluddin, M., and Brasier, A. R. (2001). Expression of respiratory syncytial virus-induced chemokine gene networks in lower airway epithelial cells revealed by cDNA microarrays. J. Virol. 75, 9044-9058.

Zheng, X., Nakamura, K., Furukawa, H., Nishibu, A., Takahashi, M., Tojo, M., Kaneko, F., Kakinuma, T., and Tamaki, K. (2003). Demonstration of TARC and CCR4 mRNA expression and distribution using in situ RT-PCR in the lesional skin of atopic dermatitis. J. Dermatol. 30, 26-32.

Zingoni, A., Soto, H., Hedrick, J. A., Stoppacciaro, A., Storlazzi, C. T., Sinigaglia, F., D’Ambrosio, D. O'Garra, A., Robinson, D., Rocchi, M., Santoni, A., Zlotnik, A., and Napolitano, M. (1998). The chemokine receptor CCR8 is preferentially expressed in Th2 but not Th1 cells. J. Immunol. 161, 547-551.

Conflict of Interest Statement: The authors declare that the research was conducted in the absence of any commercial or financial relationships that could be construed as a potential conflict of interest.

Received: 17 June 2011; accepted: 26 July 2011; published online: 08 August 2011. Citation: McCully $M L$ and Moser B (2011) The human cutaneous chemokine system. Front. Immun. 2:33. doi: 10.3389/fimmu.2011.00033

This article was submitted to Frontiers in Chemoattractants, a specialty of Frontiers in Immunology.

Copyright (C) 2011 McCully and Moser. This is an open-access article subject to a non-exclusive license between the authors and Frontiers Media SA, which permits use, distribution and reproduction in other forums, provided the original authors and source are credited and other Frontiers conditions are complied with. 